Check for updates

Cite this: J. Mater. Chem. B, 2021 9, 4963

\title{
Engineering of stealth (maghemite/PLGA)/chitosan (core/shell)/shell nanocomposites with potential applications for combined MRI and hyperthermia against cancer
}

\author{
Fátima Fernández-Álvarez, (D) a Carlos Caro, (D) b Gracia García-García, (D) ac \\ María Luisa García-Martín (iD bd and José L. Arias (ID *aef
}

\begin{abstract}
(Maghemite/poly(D,L-lactide-co-glycolide))/chitosan (core/shell)/shell nanoparticles have been prepared reproducibly by nanoprecipitation solvent evaporation plus coacervation (production performance $\approx 45 \%$, average size $\approx 325 \mathrm{~nm}$ ). Transmission electron microscopy, energy dispersive X-ray spectroscopy, electrophoretic determinations, and X-ray diffraction patterns demonstrated the satisfactory embedment of iron oxide nanocores within the solid polymer matrix and the formation of an external shell of chitosan in the nanostructure. The adequate magnetic responsiveness of the nanocomposites was characterized in vitro by hysteresis cycle determinations and by visualization of the nanosystem under the influence of a $0.4 \mathrm{~T}$ permanent magnet. Safety and biocompatibility of the (core/shell)/shell particles were based on in vitro haemocompatibility studies and cytotoxicity tests against HFF-1 human foreskin fibroblasts and on ex vivo toxicity assessments on tissue samples from Balb/c mice. Transversal relaxivities, determined in vitro at a low magnetic field of $1.44 \mathrm{~T}$, demonstrated their capability as $T_{2}$ contrast agents for magnetic resonance imaging, being comparable to that of some iron oxide-based contrast agents. Heating properties were evaluated in a high frequency alternating electromagnetic gradient: a constant maximum temperature of $\approx 46{ }^{\circ} \mathrm{C}$ was generated within $\approx 50$ min, while antitumour hyperthermia tests on T-84 colonic adenocarcinoma cells proved the relevant decrease in cell viability (to $\approx 39 \%$ ) when treated with the nanosystem under the influence of that electromagnetic field. Finally, in vivo magnetic resonance imaging studies and ex vivo histology determinations of iron deposits postulated the efficacy of chitosan to provide long-circulating capabilities to the nanocomposites, retarding nanoparticle recognition by the mononuclear phagocyte system. To our knowledge, this is the first study describing such a type of biocompatible and long-circulating nanoplatform with promising theranostic applications (biomedical imaging and hyperthermia) against cancer.
\end{abstract}

Received 19th February 2021, Accepted 10th May 2021

DOI: $10.1039 / \mathrm{d} 1 \mathrm{tb} 00354 \mathrm{~b}$

rsc.li/materials-b disease. ${ }^{1-4}$ Talking about chemotherapy, antitumour drugs and/ or genes have generated significant therapeutic outcomes (when given alone or in combination regimens), and the formulation of biodegradable and biocompatible nanoparticles (NPs) has facilitated the controlled and site-specific delivery of these agents. ${ }^{5,6}$ This important input has contributed to overcome the typical problems of cancer chemotherapy (responsible for the use of the high doses inducing acute toxicity): ${ }^{7,8}$ (i) unfavourable physical chemistry (e.g. hydrophobic character) and pharmacokinetics (rapid metabolism and short plasma half-life) of the active agent; (ii) widespread biodistribution and extravasation in non-targeted areas; (iii) low selectivity toward malignant cells; and (iv) susceptibility to induce chemoresistance in cancer cells.

These barriers have also been described for signal emitters or contrast agents, such as radionuclides, luminophores, or 
magnetic resonance imaging (MRI) contrast agents, therefore defining the little sensitivity and limited efficacy of current imaging techniques in the (early) diagnosis and follow-up of cancer. Nanoparticulate systems have been engineered satisfactorily to beat these challenges. ${ }^{9,10}$ They even have generated promising results when expanded to alternative treatment options against cancer, i.e. hyperthermia, ${ }^{11,12}$ photodynamic therapy, ${ }^{13,14}$ and photothermal therapy. ${ }^{15,16}$

Introducing passive and active targeting concepts in the engineering of all these nanosystems has been described to optimize their in vivo fate (and efficacy). ${ }^{17,18}$ Passive targeting strategies, taking advantage of the enhanced permeability and retention (EPR) effect, are based on the formulation of longcirculating or stealth NPs. ${ }^{19}$ They are typically prepared by coating the particle surface with a hydrophilic polymer, typically poly(ethylene glycol) (PEG), to protect the NP from opsonization by repelling plasma proteins. ${ }^{20}$

With respect to the active targeting strategies, they are characteristically based on: (i) the surface functionalization of NPs with molecules that can bind selectively to ligands unique to cancer cells (ligand- or receptor-mediated targeting), ${ }^{21,22}$ and/or (ii) the engineering of stimuli-sensitive carriers. The latter are NPs that can experience alterations in their structure and physical characteristics under changes in the environment, resulting in the specific (triggered) release of therapeutics at the targeted site. ${ }^{23,24}$

Building nanostructures joining both passive and active targeting functionalities has further resulted in better results in the diagnosis ${ }^{25}$ and therapy ${ }^{26,27}$ of cancer. Superparamagnetic iron oxides, e.g. magnetite $\left(\mathrm{Fe}_{3} \mathrm{O}_{4}\right)$ and maghemite $\left(\gamma-\mathrm{Fe}_{2} \mathrm{O}_{3}\right)$, can contribute notably to the formulation of these advanced nanoplatforms, owing to their magnetic targeting capacity, ${ }^{28-30}$ in combination with their versatility as agents in both magnetic antitumour hyperthermia ${ }^{31,32}$ and MRI. ${ }^{33,34}$ As a consequence, they are considered of interest when engineering theranostic NPs against cancer, ${ }^{29,35,36}$ in which they can assure MRI contrast, antitumour magnetic hyperthermia, and magnetic targeting and magnetic-based cargo delivery functionalities. The structure of these advanced nanoplatforms based on iron oxides frequently involves a core/shell construction in which the magnetic colloids are embedded in a polymer $^{37,38}$ or lipid $^{39,40}$ matrix, for the enrichment of their properties, such as colloidal stability, biocompatibility, safety, bioavailability, targeting and controlled release. In this context, poly(D,L-lactide-co-glycolide) (PLGA), a Food and Drug Administration (FDA)-approved polymer, demonstrated outstanding applications due to its biocompatibility, biodegradability, and drug vehiculization capabilities (adequate drug loading values along with biphasic controlled drug release properties). ${ }^{41-43}$ Remarkably, the latter characteristic includes a pH-triggered drug delivery to the cancer site, given the accelerated degradation of the polymer at the acidic intratumoural $\mathrm{pH}^{44,45}$ Furthermore, PLGA has been also proposed to formulate thermoresponsive delivery systems facilitating a heat-triggered drug release at the targeted site. ${ }^{46-48}$ All these are the main reasons that could justify the inclusion of the polymer as the inner shell of a (core/shell)/shell nanostructure. As a result, the PLGA shell would provide $\mathrm{pH}$ - and heat (hyperthermia)-responsive functionalities to this composite nanoplatform for the selective delivery of therapeutic molecules (drugs and/or genes) to malignant cells. Chitosan (CS) has also been used to prepare biocompatible, biodegradable, and nontoxic magnetic NPs, ${ }^{37,49-51}$ providing controlled release of many active agents. This water-soluble, low molecular weight $\left(M_{\mathrm{W}}\right)$, biodegradable and biocompatible polymer has recently been proposed as an interesting alternative to PEG chains when engineering stealth NPs. It can provide a hydrophilic stealth coating on NPs to camouflage them from the mononuclear phagocyte system (MPS), thus preventing premature clearance from systemic circulation. ${ }^{52-54}$ The positive surface electric charge provided by CS to the NP surface could also contribute to the lack of binding with opsonins, thereby contributing to evading phagocytosis and prolonging blood circulation. ${ }^{55}$

Surface modification of PLGA NPs with a CS shell is possible owing to attractive electrostatic interactions between the negatively charged PLGA particles and the positively charged CS. ${ }^{56,57}$ Additional benefits of CS functionalization are the optimization of the sustained drug release capabilities ${ }^{58-60}$ and the enhancement of the uptake by targeted cells. ${ }^{61-64}$ Therefore, CS surface coating onto these drug- and geneloaded PLGA nanosystems may help in improving their biodistribution and therapeutic effects. ${ }^{65,66}$ This conceptualization has been recently applied to the formulation of magnetopolymer particles, in which a $\left(\mathrm{Fe}_{3} \mathrm{O}_{4} / \mathrm{PLGA}\right) / \mathrm{CS}$ (core/shell)/shell structure was described. ${ }^{67-69}$

In this contribution, we develop a reproducible procedure to formulate $\left(\gamma-\mathrm{Fe}_{2} \mathrm{O}_{3} / \mathrm{PLGA}\right) / \mathrm{CS}$ NPs. Generation of this (core/ shell)/shell nanostructure was evaluated by transmission electron microscopy and elemental analysis, and by comparing the electrical surface properties of the nanocomposite to those of $\gamma-\mathrm{Fe}_{2} \mathrm{O}_{3}$ /PLGA and CS particles. Mineralogical crystallinity of the $\gamma-\mathrm{Fe}_{2} \mathrm{O}_{3}$ nuclei embedded in the polymer matrix was investigated by X-ray diffractometry. Short-term colloidal stability in water was evaluated at $4.0{ }^{\circ} \mathrm{C}$, while magnetic evaluations helped in analysing the magnetic responsiveness. Toxicity assessment was focused on blood compatibility studies, cytotoxicity tests on HFF-1 human foreskin fibroblasts, and haematoxylin and eosin (H\&E) staining of tissue samples from $\mathrm{Balb} / \mathrm{c}$ mice. A preliminary analysis of the potential use of the nanocomposites as MRI contrast agents was accomplished in vitro, while their antitumour hyperthermia capabilities were analysed under the influence of a high frequency alternating electromagnetic field in T-84 cells. Finally, in vivo distribution of the particles was determined by dynamic MRI and by Prussian blue (PB) visualization of iron deposits in tissue samples.

\section{Materials and methods}

\section{Materials}

All chemicals were of analytical quality and were used as received without further purification. $\mathrm{Fe}\left(\mathrm{NO}_{3}\right)_{3} \cdot 9 \mathrm{H}_{2} \mathrm{O}\left(M_{\mathrm{W}}: 404 \mathrm{~g} \mathrm{~mol}^{-1}\right)$, 
$\mathrm{FeCl}_{2} \cdot 4 \mathrm{H}_{2} \mathrm{O}\left(M_{\mathrm{W}}: 198.81 \mathrm{~g} \mathrm{~mol}^{-1}\right), \mathrm{KNO}_{3}, \mathrm{HClO}_{4}(70 \%$, American Chemical Society, ACS specification), $\mathrm{HCl}$ (37\%, ACS specification), EtOH $96^{\circ}$, and $\mathrm{CH}_{3} \mathrm{COOH}(\geq 98 \%$, ACS specification) from VWR International, LLC (Spain). Low $M_{\mathrm{W}} \mathrm{CS}(\approx 50000$ to $190000 \mathrm{Da}$, determined by viscosity measurement; polydispersity not determined by the laboratory; $75-85 \%$ deacetylated; 99\% purity level), Resomer ${ }^{\circledR}$ RG 502 H [PLGA, 50:50 poly(D,Llactide): poly(glycolide), $M_{\mathrm{W}} \approx 7000$ to $17000 \mathrm{Da}$, inherent viscosity $\approx 0.16$ to $\left.0.24 \mathrm{dL} \mathrm{g}^{-1}\right]$, ethylenediaminetetraacetic acid (EDTA), $\mathrm{NaH}_{2}\left(\mathrm{C}_{3} \mathrm{H}_{5} \mathrm{O}(\mathrm{COO})_{3}\right), 4^{\prime}$,6-diamidino-2-phenylindole (DAPI) dihydrochloride, phosphate buffered saline (PBS), 3-(4,5-dimethylthiazol-2-yl)-3,5-diphenyl tetrazolium bromide (MTT) solution, xylene, $\mathrm{CH}_{2} \mathrm{O}, \mathrm{K}_{4}\left[\mathrm{Fe}(\mathrm{CN})_{6}\right]$, and ethanol $99^{\circ}$ from Merck KGaA (Germany). Kolliphor ${ }^{\circledR}$ P-188 from BASF (Germany). $\mathrm{Cl}_{3} \mathrm{FeH}_{12} \mathrm{O}_{6}\left(M_{\mathrm{W}}: 270.32 \mathrm{~g} \mathrm{~mol}^{-1}\right)$, polyvinyl alcohol (PVA, $M_{\mathrm{W}}$ : $\left.72000 \mathrm{~g} \mathrm{~mol}^{-1}\right)$, HPLC-grade acetone, and $\mathrm{NH}_{3}(30 \%$, ACS specification) from Panreac (Spain). $\mathrm{Na}_{2} \mathrm{SO}_{4}$ and oleic acid ( $\geq 99 \%$, ACS specification) from Guinama S. L. (Spain). TO$\mathrm{PRO}^{\mathbb{R}}-3$ iodide and dimethyl sulfoxide (DMSO) from ACROS Organics $^{\mathrm{TM}}$ (Belgium). Dulbecco's modified Eagle's medium (DMEM), fetal bovine serum (FBS), $2 \mathrm{mM}_{\text {L-glutamine, Gibco }}{ }^{\text {TM }}$ penicillin-streptomycin solution (100 IU $\mathrm{mL}^{-1}$ ), and Triton ${ }^{\circledR}$ X-100 from ThermoFisher Scientific Inc. (USA). Deionized and filtered water was used in all the experiments (Milli-Q Academic $^{\circledR}$, Millipore, France).

\section{Formulation of $\left(\gamma-\mathrm{Fe}_{2} \mathrm{O}_{3} / \mathrm{PLGA}\right) / \mathrm{CS}$ (core/shell)/shell nanocomposites}

$\mathrm{Fe}_{3} \mathrm{O}_{4}$ NPs were obtained by chemical co-precipitation. ${ }^{70}$ The reaction started with the simultaneous and slow addition of $40 \mathrm{~mL}$ of $1 \mathrm{M} \mathrm{FeCl}_{3}$ solution and $10 \mathrm{~mL}$ of $2 \mathrm{M} \mathrm{FeCl}_{2}$ solution (in $2 \mathrm{M} \mathrm{HCl}$ ) to $0.5 \mathrm{~L}$ of $0.7 \mathrm{M} \mathrm{NH}_{3}$ solution, at room temperature and under mechanical stirring (700 rpm; IKA ${ }^{\circledR}$ Eurostar 60 Digital Constant-Speed Mixer, Germany). Stirring was continued for $30 \mathrm{~min}$. Long-term stabilization of the $\mathrm{Fe}_{3} \mathrm{O}_{4}$ particles was then achieved by magnetic isolation (permanent magnet of $0.4 \mathrm{~T}$ ) from the $\mathrm{NH}_{3}$ media and re-dispersion in $0.25 \mathrm{~L}$ of $2 \mathrm{M} \mathrm{HClO}_{4}$ solution. After $12 \mathrm{~h}$ of contact, the NPs were isolated using a magnet $(0.4 \mathrm{~T})$, and their oxidation into $\gamma-\mathrm{Fe}_{2} \mathrm{O}_{3}$ was accomplished with $\mathrm{Fe}\left(\mathrm{NO}_{3}\right)_{3}(0.6 \mathrm{~L}, 0.34 \mathrm{M})$ at $90{ }^{\circ} \mathrm{C}$ during $30 \mathrm{~min} .{ }^{71}$ Finally, cleaning of the $\gamma-\mathrm{Fe}_{2} \mathrm{O}_{3}$ NPs was done by repeated cycles of centrifugation $(30 \mathrm{~min}$ at $8500 \mathrm{rpm}$, Centrifuge 5804; Eppendorf Ibérica S. L. U., Spain) until the conductivity of the supernatant was $\leq 10 \mu \mathrm{S} \mathrm{cm}{ }^{-1}$ (Crison Microcm 2202 conductivity meter, Hach Lange Spain S. L. U., Spain).

Incorporation of oleic acid onto the surface of iron oxide NPs has been described to result in a change in the surface characteristics from hydrophilic to hydrophobic. ${ }^{72,73}$ This surface transformation in the $\gamma-\mathrm{Fe}_{2} \mathrm{O}_{3}$ particles may favour their incorporation into the PLGA matrix when preparing the $\gamma-\mathrm{Fe}_{2} \mathrm{O}_{3} /$ PLGA (core/shell) particles. To that aim, $3.5 \mathrm{~mL}$ of an ethanolic solution of oleic acid $(1 \%, \mathrm{v} / \mathrm{v})$ was added under sonication ( $42 \mathrm{kHz}$ sonication frequency, $100 \mathrm{~W}$ output power; Bransonic $^{\circledR}$ ultrasonic bath, Branson Ultrasonics Corporation, USA) to $14.25 \mathrm{mg}$ of iron oxide nuclei ( $1: 1.25$ iron : oleic molar ratio). ${ }^{74}$ Sonication was continued for $60 \mathrm{~min}$. The oleic acidtreated $\gamma-\mathrm{Fe}_{2} \mathrm{O}_{3}$ nanocores were isolated from the EtOH solution using a permanent magnet of $0.4 \mathrm{~T}$ and washed twice with $1 \mathrm{~mL}$ of acetone.

The formulation of the $\gamma-\mathrm{Fe}_{2} \mathrm{O}_{3} / \mathrm{PLGA}$ (core/shell) particles (of $3: 4 \gamma-\mathrm{Fe}_{2} \mathrm{O}_{3}$ : PLGA weight ratio) was based on the nanoprecipitation solvent evaporation technique, which has been previously used to prepare pure PLGA NPs. ${ }^{21,75,76}$ The procedure started with the addition of an organic phase containing PLGA and the oleic acid-modified iron oxide nuclei (19 mg and $14.25 \mathrm{mg}$ in $5 \mathrm{~mL}$ of acetone, respectively) to $10 \mathrm{~mL}$ of an aqueous solution of PVA $(1 \%, w / v)$, under sonication (Branson Sonifier 450, Emerson Electric Co., USA). The microtip of the ultrasonic homogenizer was placed in the aqueous phase, leaving $1 \mathrm{~cm}$ distance from the bottom of the vial. To minimize the evaporation of the liquid, an aluminium foil was placed over the opening of the vial. Pulsed mode, with a cycle of $40 \%$, sonication output of $20 \%$, and sonication time of $1 \mathrm{~min}$, avoided foaming and enabled adequate temperature control. The sample vial was surrounded with ice during the sonication process. Acetone was evaporated to obtain an aqueous dispersion of $\gamma-\mathrm{Fe}_{2} \mathrm{O}_{3}$ /PLGA NPs (Büchi Rotavapor ${ }^{\circledR}$ rotary evaporator, Büchi, Switzerland), and the NPs were then cleaned by repeated magnetic separation from the aqueous medium ( $0.4 \mathrm{~T}$ permanent magnet) and redispersion in water, until the conductivity of the supernatant was $\leq 10 \mu \mathrm{S} \mathrm{cm}^{-1}$.

Finally, $\left(\gamma-\mathrm{Fe}_{2} \mathrm{O}_{3} / \mathrm{PLGA}\right) / \mathrm{CS}$ (core/shell)/shell particles (of $4: 3$ $\gamma-\mathrm{Fe}_{2} \mathrm{O}_{3} /$ PLGA : CS weight ratio) were obtained by a coacervation method, which was also used to obtain pure CS NPs. ${ }^{77-79}$ Initially, $10.5 \mathrm{mg}$ of CS was progressively dissolved in $25 \mathrm{~mL}$ of an aqueous solution of acetic acid $(2 \%, \mathrm{v} / \mathrm{v})$ containing $1 \% \quad(\mathrm{w} / \mathrm{v})$ Kolliphor ${ }^{\circledR} \quad \mathrm{P}-188$, under mechanical stirring (1000 rpm), and $14 \mathrm{mg}$ of $\gamma-\mathrm{Fe}_{2} \mathrm{O}_{3} /$ PLGA NPs was then homogeneously dispersed in this aqueous phase under mechanical stirring $(700 \mathrm{rpm})$. At that moment, $6.25 \mathrm{~mL}$ of $20 \%(\mathrm{w} / \mathrm{v})$ solution of $\mathrm{Na}_{2} \mathrm{SO}_{4}$ was added drop-wise $\left(1.25 \mathrm{~mL} \mathrm{~min}^{-1}\right)$ under sonication (cycle of $50 \%$, sonication output of $20 \%$, and sonication time of $15 \mathrm{~min}$ ) to obtain the aqueous dispersion of (core/shell)/ shell particles. The $\left(\gamma-\mathrm{Fe}_{2} \mathrm{O}_{3} / \mathrm{PLGA}\right) / \mathrm{CS}$ NPs were cleaned repeatedly by magnetic separation and redispersion in water until the conductivity of the supernatant was $\leq 10 \mu \mathrm{S} \mathrm{cm}^{-1}$. In contrast, cleaning of the pure CS particles was achieved by repeated cycles of centrifugation $(30 \mathrm{~min}$ at $9500 \mathrm{rpm}$, Centrikon T-124 high speed centrifuge, Kontron, France) and redispersion in water, until the conductivity of the supernatant was $\leq 10 \mu \mathrm{S} \mathrm{cm}^{-1}$.

All experiments were carried out in triplicate $(n=3)$, and the particle production performance (yield, \%) was determined by using eqn (1):

$$
\text { Yield }(\%)=\frac{\text { amount of NPs obtained }(\mathrm{mg})}{\text { summation of materials used in the preparation of these NPs }(\mathrm{mg})} \times 100
$$




\section{Characterization}

Particle size, size distribution (polydispersity index, PdI), and zeta potential $(\zeta)$ were determined after dilution of the colloids in water $(\approx 0.1 \%, w / v)(n=3)$ (Zetasizer Nano-ZS, Malvern Instruments Ltd., UK). The cell temperature was $25.0 \pm 0.5{ }^{\circ} \mathrm{C}$, and the detection angle was $60^{\circ}$.

High resolution transmission electron microscopy (HRTEM), high-angle annular dark field scanning transmission electron microscopy (HAADF-STEM), and annular bright field scanning transmission electron microscopy (ABF-STEM) (Titan G2 60-300 FEI microscope, Thermofisher Scientific Inc., USA; operating at an accelerating voltage of $300 \mathrm{kV}$ ) helped in visualizing the nanostructures and in evaluating the complete coating of the cores by the polymeric matrices. Drops of the dilute aqueous NP dispersions $(\approx 0.1 \%, \mathrm{w} / \mathrm{v})$ were poured on formvar/carbon-coated copper microgrids and dried in a convection oven $\left(25.0 \pm 0.5{ }^{\circ} \mathrm{C}\right.$, 24 h) (J. P. Selecta, S. A., Spain). Elemental analysis was performed during the TEM measurements by using an energy dispersive X-ray (EDX) spectrometer (Bruker Nano $\mathrm{GmbH}$, Germany).

Short-term colloidal stability at $4.0 \pm 0.5{ }^{\circ} \mathrm{C}$ was tested in water $(n=3)$. The aqueous dispersion of (core/shell)/shell NPs $\left(1 \mathrm{mg} \mathrm{mL}{ }^{-1}, \mathrm{pH} \approx 6\right)$ was stored at this temperature, and the evolution of size, PdI and $\zeta$ values of the particles was measured as a function of time following storage. These are parameters that are considered as benchmarks for characterizing the stability of colloidal systems. ${ }^{29}$ At each sampling time a formulation was tested and not returned to the storage conditions.

CS coating onto the $\left(\gamma-\mathrm{Fe}_{2} \mathrm{O}_{3} / \mathrm{PLGA}\right)$ particles was qualitatively evaluated by determining the influence of $\mathrm{pH}(\mathrm{pH}$ values from 3 to 9 , in the presence of $10^{-3} \mathrm{M} \mathrm{KNO}_{3}$ ) on the $\zeta$ values of these NPs. Determinations were done at room temperature ( $n=12)$, after $24 \mathrm{~h}$ of contact under mechanical stirring (200 rpm, Boeco universal orbital shaker OS-10, Boeco, Germany).

Mineralogical purity and crystallinity of iron oxide-based NPs are important factors that contribute to their magnetic responsiveness. ${ }^{29,80,81}$ In view of this, characterization of the internal structure of the $\gamma-\mathrm{Fe}_{2} \mathrm{O}_{3}$ nuclei and the $\left(\gamma-\mathrm{Fe}_{2} \mathrm{O}_{3} /\right.$ PLGA $)$ and $\left(\gamma-\mathrm{Fe}_{2} \mathrm{O}_{3} / \mathrm{PLGA}\right) / \mathrm{CS}$ particles was done by X-ray diffractometry (Philips PW1710 diffractometer, The Netherlands), using the Debye-Scherrer method with $\mathrm{Cu}-\mathrm{K} \alpha$ radiation of $\lambda=1.5405 \AA$.

The magnetic characteristics of the (core/shell) and (core/ shell)/shell NPs were determined at $25.0 \pm 0.5{ }^{\circ} \mathrm{C}$, under the influence of a magnetic field ranging from -4000 to $4000 \mathrm{kA} \mathrm{m}^{-1}$ (Manics DSM-8 vibrating magnetometer, France). Additionally, the magnetic field responsive behaviour of a $0.1 \%(\mathrm{w} / \mathrm{v})$ aqueous NP dispersion was qualitatively analysed by optical microscope visualization of the colloid under exposure to a $0.4 \mathrm{~T}$ permanent magnet (Olympus BX40F4 microscope, Olympus Optical Co. Ltd, Japan). A Gilmont (USA) micrometer syringe was used to deposit gently one droplet $(\approx 10 \mu \mathrm{L})$ of the colloid on a dry and clean microscope glass slide. The magnet was situated at a distance of $3 \mathrm{~cm}$ from the centre of the droplet, and images were then captured with a video camera at $t=5 \mathrm{~s}$.

Iron concentration was determined by inductively coupled plasma-high resolution mass spectrometry (ICP-HRMS, Element
XR High Resolution ICP-MS system, ThermoFisher Scientific Inc., USA $).{ }^{82}$ Prior to analysis, the $\left(\gamma-\mathrm{Fe}_{2} \mathrm{O}_{3} / \mathrm{PLGA}\right)$ particles and $\left(\gamma-\mathrm{Fe}_{2} \mathrm{O}_{3} / \mathrm{PLGA}\right) / \mathrm{CS}$ particles were disintegrated by adding $2.5 \mathrm{~mL}$ of aqua regia $\left(3: 1 \mathrm{HNO}_{3}: \mathrm{HCl}\right.$ molar ratio) to $25 \mu \mathrm{L}$ of $0.1 \%(\mathrm{w} / \mathrm{v})$ aqueous NP dispersion. After $12 \mathrm{~h}$ of contact, water was added to the volumetric flask (final volume: $25 \mathrm{~mL}$ ) and the sample was analysed.

Longitudinal $\left(r_{1}\right)$ and transversal $\left(r_{2}\right)$ relaxivities of (core/ shell) NPs and (core/shell)/shell NPs were determined in vitro at a low magnetic field $\left(1.44 \mathrm{~T}\right.$ ) and $37.0 \pm 0.5{ }^{\circ} \mathrm{C}$ (Bruker Minispec MQ-60 spectrometer, Bruker BioSpin, Germany), ${ }^{83}$ using iron concentrations ranging from 0.25 to $2.00 \mathrm{mM}$. Transverse (or spin-spin) relaxation time $\left(T_{2}\right)$ values were measured by using the standard Carr-Purcell-Meiboom-Gill (CPMG) pulse sequence, while the longitudinal (or spin-lattice) relaxation time $\left(T_{1}\right)$ was measured using the standard inversion-recovery pulse sequence.

\section{Haemocompatibility}

Interaction of $\left(\gamma-\mathrm{Fe}_{2} \mathrm{O}_{3} / \mathrm{PLGA}\right) \mathrm{NPs}$ and $\left(\gamma-\mathrm{Fe}_{2} \mathrm{O}_{3} / \mathrm{PLGA}\right) / \mathrm{CS}$ NPs with blood components was evaluated to postulate their possibilities for clinical applications, i.e. magnet-guided chemotherapy plus hyperthermia. The methodology has been detailed previously, ${ }^{21,39,84,85}$ being appropriate in the evaluation of nanoformulations. In brief, blood samples were obtained from two healthy female adults ( 24 and 45 year old), and poured into flasks containing EDTA (prior to haemolysis, and platelet activation assays) or $\mathrm{NaH}_{2}\left(\mathrm{C}_{3} \mathrm{H}_{5} \mathrm{O}(\mathrm{COO})_{3}\right)$ (prior to complement system activation, and plasma clotting time experiments). The colloids were kept in contact with blood aliquots to evaluate their impact on erythrocytes, coagulation, and the complement system $(n=3)$. PBS was used as a negative control. A validated ultraviolet-visible (UV-Vis) spectrophotometric method was used in the study.

\section{In vitro proliferation studies}

HFF-1 human foreskin fibroblasts were cultured in DMEM supplemented with $2 \mathrm{mM}$ L-glutamine, 10\% FBS and 1\% penicillin-streptomycin, at $37.0 \pm 0.5{ }^{\circ} \mathrm{C}$ in a humidified atmosphere of $5 \% \mathrm{CO}_{2}$ [MCO-19AIC(UV) $\mathrm{CO}_{2}$ incubator, Sanyo, Japan]. Then, the cells in the exponential growth phase were seeded into 96-well plates $\left(10^{4}\right.$ cells per well) and were preincubated for $24 \mathrm{~h}\left(37.0 \pm 0.5{ }^{\circ} \mathrm{C}, 5 \% \mathrm{CO}_{2}\right)$, and the medium in the wells was replaced with fresh medium containing $\gamma-\mathrm{Fe}_{2} \mathrm{O}_{3} /$ PLGA or $\left(\gamma-\mathrm{Fe}_{2} \mathrm{O}_{3} / \mathrm{PLGA}\right) / \mathrm{CS}$ particles (0.1 to $100 \mu \mathrm{g} \mathrm{mL} \mathrm{mL}^{-1}$ of iron concentration).

Following the ISO-10993-5 standard, ${ }^{86}$ cell viability was tested (in quadruplicate) by the MTT proliferation assay, by determining mitochondrial dehydrogenase activity. After $24 \mathrm{~h}$ of contact, $200 \mu \mathrm{L}$ of MTT solution in cell culture medium $\left(0.5 \mathrm{mg} \mathrm{mL} \mathrm{m}^{-1}\right)$ was added to each well. After incubation for $2 \mathrm{~h}$ at $37.0 \pm 0.5{ }^{\circ} \mathrm{C}$ and $5 \% \mathrm{CO}_{2}$, the culture medium was removed and the resultant formazan crystals were solubilized with $200 \mu \mathrm{L}$ of DMSO. The absorbance of converted dye, which is proportional to the number of viable cells (metabolically active cells), was measured at $550 \mathrm{~nm}$ using a Dynatech MR7000 
microplate reader (Dynatech Laboratories, Inc., USA). Triton ${ }^{\circledR}$ $\mathrm{X}-100(1 \%, \mathrm{v} / \mathrm{v})$ was added to the positive control wells. Relative cell viability (RCV, \%) and the error related to control wells containing cell culture medium without NPs were calculated by eqn (2) and (3), respectively:

$$
\mathrm{RCV}(\%)=\frac{A_{\text {test }}-A_{\text {positive controls for the NPs }}}{A_{\text {negative controls for the NPs }}-A_{\text {positive controls for the NPs }}} \times 100
$$

$$
\text { Error }(\%)=\mathrm{RCV}_{\text {test }} \times \sqrt{\left(\frac{\sigma_{\text {test }}}{A_{\text {test }}}\right)^{2}+\left(\frac{\sigma_{\text {control }}}{A_{\text {control }}}\right)^{2}}
$$

where $A$ is the absorbance and $\sigma$ is the standard deviation (SD).

HFF-1 cells were also cultured, similarly as described above, for the cell morphology studies, in quintuplicate. After $24 \mathrm{~h}$ of contact with the $\gamma-\mathrm{Fe}_{2} \mathrm{O}_{3} / \mathrm{PLGA}$ or $\left(\gamma-\mathrm{Fe}_{2} \mathrm{O}_{3} / \mathrm{PLGA}\right) / \mathrm{CS}$ particles (0.1 to $100 \mu \mathrm{g} \mathrm{mL} \mathrm{m}^{-1}$ of iron concentration), Triton ${ }^{\circledR} \mathrm{X}-100$ $(1 \%, v / v)$ was added to the positive control wells. After $15 \mathrm{~min}$, all the wells were stained with DAPI (dilution $1: 3000)$ to label the cell nucleus and with TO-PRO ${ }^{\mathbb{R}}-3$ iodide (dilution $1: 1000$ ) to label only dead cells. 10 random image fields captured per well were analysed $(20 \times$ long working distance, numerical aperture 0.45, air objective lens; Operetta ${ }^{\circledR}$ High Content Imaging System, PerkinElmer, Inc., USA) being taken for each field fluorescence image for DAPI and TO-PRO ${ }^{\mathbb{R}}-3$ iodide, plus a bright field image. Cell mortality (\%) was calculated automatically by Operetta ${ }^{\circledR}$ Harmony software (PerkinElmer, Inc., USA), whereby live or dead nuclei were identified from the DAPI staining. Dead cells (\%) were then determined by the number of nuclei presenting also high levels of TO-PRO ${ }^{\circledR}-3$ iodide staining.

\section{Magnetic fluid hyperthermia experiments}

The in vitro heating behaviour of an aqueous dispersion of $\left(\gamma-\mathrm{Fe}_{2} \mathrm{O}_{3} / \mathrm{PLGA}\right) / \mathrm{CS}$ NPs $\left(10 \mathrm{mg} \mathrm{mL} \mathrm{mL}^{-1}, 5 \mathrm{~mL}\right)$ compared to a control formulation (i.e. aqueous medium without particles) was investigated at $25.0 \pm 0.5{ }^{\circ} \mathrm{C}(n=3)$. To that aim, a high frequency alternating electromagnetic field induced by a power supply equipped with a solenoid was used (diameter: $20 \mathrm{~mm}$; length: $100 \mathrm{~mm}$; number of spirals: 70). Magnetic field frequency and intensity values were $250 \mathrm{kHz}$ and $4 \mathrm{kA} \mathrm{m}^{-1}$, respectively, which were within the average commonly fixed to do such characterization ${ }^{37,39,49,87}$ and below the human tolerance threshold. ${ }^{88}$ Temperature data were continuously logged using a fiber optic thermometry unit connected to a laptop computer.

The antitumour magnetic hyperthermia activity of the $\left(\gamma-\mathrm{Fe}_{2} \mathrm{O}_{3} / \mathrm{PLGA}\right) / \mathrm{CS}$ NPs was evaluated on the T-84 colonic adenocarcinoma cell line (American Type Culture Collection, USA). Detailed description of the procedure can be found in the literature. ${ }^{39,89,90}$ Briefly, cells were seeded into 24-well plates $\left(10^{4}\right.$ cells per well) and incubated for $2 \mathrm{~h}$ in the presence (or absence) of the NPs $(0.4 \%, \mathrm{w} / \mathrm{w})\left(37.0 \pm 0.5{ }^{\circ} \mathrm{C}, 5 \% \mathrm{CO}_{2}\right)$. Then, cell suspensions were centrifuged (10 $\mathrm{min}$ at $4000 \mathrm{rpm}$ ) to separate the cells from the unbound or weakly bound magnetic nanocomposites, and the cell pellets were re-suspended in $200 \mu \mathrm{L}$ of culture medium. The oscillating electromagnetic gradient was then applied (or not) to the cell suspensions for $1 \mathrm{~h}$, and the cells were incubated at room temperature for $30 \mathrm{~min}$ and then washed twice in PBS and suspended in the culture medium. Finally, the cells were seeded into 24 -well plates $\left(10^{4}\right.$ cells per well $)$ and kept under culture conditions for $48 \mathrm{~h}\left(37.0 \pm 0.5{ }^{\circ} \mathrm{C}, 5 \% \mathrm{CO}_{2}\right)$. Finally, cell viability was evaluated by the MTT-based colorimetric assay.

\section{In vivo MRI studies}

All the in vivo experiments were done in the BIONAND Animal Experimentation Service. They were approved by the local Animal Care Committee and performed in compliance with the EU Directive 2010/63/EU (2010) and the Spanish legislation for the care and use of laboratory animals (R.D. 53/2013).

Male Balb/c mice, $22 \mathrm{~g}$ in weight (Janvier Labs, France), were anesthetized with $1 \%$ isoflurane, and their tail veins were cannulated. Then, the mice were introduced in the MRI system. Respiratory signals and body temperature were monitored throughout the MRI experiment. The $\left(\gamma-\mathrm{Fe}_{2} \mathrm{O}_{3} / \mathrm{PLGA}\right)$ or $\left(\gamma-\mathrm{Fe}_{2} \mathrm{O}_{3} / \mathrm{PLGA}\right) / \mathrm{CS}$ NPs were intravenously injected at an iron concentration of $5 \mathrm{mg} \mathrm{kg}{ }^{-1}$. The study was performed in triplicate on a Bruker BioSpec ${ }^{\circledR} 9.4 \mathrm{~T}$ animal MRI system (BioSpec 94/20 USR superconducting magnet system, Bruker BioSpin, Germany) equipped with a $400 \mathrm{mT} \mathrm{m}^{-1}$ gradient and a $40 \mathrm{~mm}$ quadrature bird-cage resonator.

High resolution $T_{2}$-weighted images were acquired using a turbo-RARE sequence with respiratory gating (echo time, TE: $16 \mathrm{~ms}$; repetition time, TR: $1000 \mathrm{~ms}$; averages: 4; in-plane resolution: $156 \mu \mathrm{m}$; and slice thickness: $1 \mathrm{~mm}$ ). Quantitative $T_{2}$ measurements were performed using a multi-echo spin echo sequence (TE ranging from 7 to $448 \mathrm{~ms}$, TR: $3500 \mathrm{~ms}$, field of view: $4 \mathrm{~cm}$, matrix size: $128 \times 128$, and slice thickness: $1 \mathrm{~mm}$ ). Time-courses were followed by using a turbo-RARE sequence with the parameters indicated above, except for only one average to improve temporal resolution (one image every $30 \mathrm{~s}$ ). The acquisition scheme was as follows: $T_{2}$-weighted, quantitative $T_{2}$ map, intravenous injection of the NPs, time-course for $35 \mathrm{~min}$, $T_{2}$-weighted, and quantitative $T_{2}$ map. The first $35 \mathrm{~min}$ timecourses were analysed semi-quantitatively using eqn (4):

$$
\operatorname{RE}(\%)=\frac{I_{t}-I_{\mathrm{o}}}{I_{\mathrm{o}}} \times 100
$$

where RE is the modulus of relative signal enhancement, $I_{\mathrm{t}}$ is the signal intensity at any given time after injection of NPs, and $I_{0}$ is the signal intensity before injection.

Biodistribution was characterized by quantitative $T_{2}$ mapping at 0,1 , and $24 \mathrm{~h}$. Average $T_{2}$ values were calculated within different regions of interest placed on the liver, spleen, kidneys, and muscle, as previously described. ${ }^{91,92}$

\section{Ex vivo histology evaluation of iron deposits and toxicity assessment}

Histology was determined by conventional optical microscopy visualization of tissue samples, at $24 \mathrm{~h}$ post-intravenous injection of $\left(\gamma-\mathrm{Fe}_{2} \mathrm{O}_{3} / \mathrm{PLGA}\right)$ and $\left(\gamma-\mathrm{Fe}_{2} \mathrm{O}_{3} / \mathrm{PLGA}\right) / \mathrm{CS}$ NPs. Mice were sacrificed and the liver, kidney, spleen, lung and heart were 
extracted. Tissues were fixed in $4 \%(\mathrm{w} / \mathrm{v})$ aqueous $\mathrm{CH}_{2} \mathrm{O}$ solution (buffered to $\mathrm{pH} 7.0 \pm 0.5$ ) for $48 \mathrm{~h}$, changing this liquid medium after $24 \mathrm{~h}$. Then, the tissue samples were dehydrated with EtOH and soaked in paraffin (at $56.0 \pm$ $0.5{ }^{\circ} \mathrm{C}$ for $2 \mathrm{~h}$, under mechanical stirring) (LEICA TP 1020 Semi-enclosed Benchtop Tissue Processor, Leica Biosystems Nussloch GmbH, Germany). Finally, the samples were embedded in paraffin (Leica EG1150 Modular Tissue Embedding Center, Leica Biosystems Nussloch GmbH, Germany), and then cut into $7 \mu \mathrm{m}$-sized sections using a microtome blade (Thermo Scientific ${ }^{\mathrm{TM}}$ HM 360 microtome, ThermoFisher Scientific Inc., USA).

Tissue samples were stained with Prussian blue (PB) to visualize iron deposits. To that aim, the tissue slides were deparaffinized, rehydrated, and immersed for $30 \mathrm{~min}$ in a freshly prepared mixture of equal parts of $20 \%(\mathrm{v} / \mathrm{v}) \mathrm{HCl}$ and $10 \%(\mathrm{w} / \mathrm{v}) \mathrm{K}_{4}\left[\mathrm{Fe}(\mathrm{CN})_{6}\right]$ solution. The tissue sections were then washed thrice in water and counter stained with nuclear fast red for 5 min. Finally, the sections were rinsed twice with distilled water, EtOH $100 \%$, followed by $100 \%$ xylene, and mounted with coverslips for observation under an optical microscope.

Tissue samples were also stained with haematoxylin and eosin (H\&E) to assess tissue architecture. Deparaffinization and rehydration of the tissue slides were done before staining with H\&E. Staining was possible by immersion of the samples for $5 \mathrm{~min}$ in $\mathrm{H}$, washing twice in water, and immersion of the tissue samples in $\mathrm{E}$ for $2 \mathrm{~min}$. The slides were then dehydrated in ascending grades of EtOH (from 70 to $100 \%$ ), cleared in $100 \%$ xylene, and mounted using glass coverslips for observation under a microscope.

\section{Statistical analysis}

Statistical analyses were done using the IBM SPSS Statistics software package (version 26.0; IBM Corporation, USA). Experimental data were expressed as mean value \pm SD. Student's $t$-test or two-way analysis of variance helped to compare results considering 95\% confidence interval. Differences were considered statistically significant at $p<0.05$.

\section{Results and discussion}

\section{Characterization}

The in vivo fate and use of magnetic colloids in biomedicine is considerably defined by their size and surface electric charge, among other relevant characteristics. Such properties can be tailored when engineering the iron oxide-based particles to prevent capture by the MPS. ${ }^{7,29}$ This may further facilitate reaching the malignant tissue by passing through the gap junction between endothelial cells of the leaky tumour vasculature (up to $\approx 600 \mathrm{~nm}$ ). ${ }^{93,94}$

The mean size (and PdI) of $\gamma-\mathrm{Fe}_{2} \mathrm{O}_{3}$ nuclei, pure CS particles, and $\left(\gamma-\mathrm{Fe}_{2} \mathrm{O}_{3} / \mathrm{PLGA}\right)$ NPs was determined by photon correlation spectroscopy (PCS), and was found to be $9.1 \pm 3.2,353.4 \pm 20.6$, and $285.3 \pm 4.2 \mathrm{~nm}$, respectively. The formulation of $\left(\gamma-\mathrm{Fe}_{2} \mathrm{O}_{3}\right)$ PLGA)/CS (core/shell)/shell NPs (of $4: 3 \quad \gamma-\mathrm{Fe}_{2} \mathrm{O}_{3} / \mathrm{PLGA}: \mathrm{CS}$ weight ratio) by coacervation reported adequate particle production performances $(\approx 45 \%)$, and appropriate size (325.8 \pm $8.5 \mathrm{~nm}$, compatible with parenteral administration) and $\zeta$ values $(23.3 \pm 0.4 \mathrm{mV})$. The stealth coating and positive surface electric charge provided by CS to the $\gamma-\mathrm{Fe}_{2} \mathrm{O}_{3} /$ PLGA nanostructure are expected to prevent the premature clearance of the (core/shell)/shell NPs from the systemic circulation, ${ }^{52-55}$ thus favouring appropriate plasma half-lives to reach the tumour site and provide clinically relevant concentrations of any given therapeutic agent. Furthermore, these positive $\zeta$ values may facilitate NP internalization by negatively charged cancer cells, thus possibly assuring the deep contact of the therapeutic molecule with intracellular targets. ${ }^{55,61-64,95,96}$

The results from short-term stability studies are compiled in Table 1. From the results, it could be hypothesized that the preparation technique may be used in the formulation of appropriately stabilized (core/shell)/shell NPs. In fact, no NP aggregation was observed, and no appreciable change in the size and surface electric charge of the nanocomposites was detected by PCS after 1 month of storage at $4.0 \pm 0.5{ }^{\circ} \mathrm{C}$ in water (Table 1).

HRTEM, HAADF-STEM, and ABF-STEM photographs ratified that the iron oxide nuclei were embedded in the polymeric matrices (Fig. 1a-d), while the EDX Fe and N element mappings of these (core/shell)/shell particles demonstrated the homogeneous distribution of $\gamma-\mathrm{Fe}_{2} \mathrm{O}_{3}$ nuclei within the NP matrix (Fig. 1e) and the coating of CS onto the $\gamma-\mathrm{Fe}_{2} \mathrm{O}_{3} /$ PLGA nanostructure (Fig. 1f). Aggregation of NPs observed in the figure was associated with the method of sample preparation (drying) for electron microscopy observations. ${ }^{38,49,97,98}$

EDX analyses also revealed the existence of the elements Fe, $\mathrm{C}, \mathrm{N}$, and $\mathrm{O}$ for the NPs (Fig. 1g). The Fe and $\mathrm{N}$ elements arise from the $\gamma-\mathrm{Fe}_{2} \mathrm{O}_{3}$ cores and CS shell, respectively. These observations, combined with data from the electrokinetic characterization of the particles (see Fig. 2a), qualitatively confirmed the formation of the $\left(\gamma-\mathrm{Fe}_{2} \mathrm{O}_{3} / \mathrm{PLGA}\right) / \mathrm{CS}$ (core/shell)/shell nanostructure. Finally, the use of copper-based grids for EM characterization contributed to the appearance of the $\mathrm{Cu}$ element in this analysis, ${ }^{38}$ while the presence of Si in the EDX spectra in such a dilute NP sample could be due to the generation of secondary fluorescence by the fluorescence detector. ${ }^{99}$

Table 1 Evolution of size ( $\mathrm{nm})$, polydispersity index (Pdl) and zeta potential $(\zeta, \mathrm{mV})$ of $\left(\gamma-\mathrm{Fe}_{2} \mathrm{O}_{3} / \mathrm{PLGA}\right) / \mathrm{CS}$ particles as a function of time. The aqueous dispersion of NPs $\left(1 \mathrm{mg} \mathrm{mL}^{-1}, \mathrm{pH} \approx 6\right)$ was stored at $4.0 \pm 0.5^{\circ} \mathrm{C}$. Experimental data are expressed as means \pm SDs of triplicate experiments $(n=3)$

\begin{tabular}{llll}
\hline $\begin{array}{l}\text { Time } \\
(\text { days })\end{array}$ & Size $(\mathrm{nm})$ & PdI & $\zeta(\mathrm{mV})$ \\
\hline 0 & $325.8 \pm 8.5$ & $0.367 \pm 0.007$ & $23.3 \pm 0.4$ \\
1 & $325.8 \pm 10.5$ & $0.439 \pm 0.070$ & $16.9 \pm 0.8$ \\
3 & $332.3 \pm 11.3$ & $0.358 \pm 0.049$ & $32.8 \pm 0.7$ \\
5 & $336.3 \pm 2.4$ & $0.335 \pm 0.043$ & $20.1 \pm 0.4$ \\
7 & $330.2 \pm 3.9$ & $0.360 \pm 0.047$ & $23.5 \pm 0.4$ \\
10 & $333.9 \pm 6.4$ & $0.302 \pm 0.029$ & $24.0 \pm 0.7$ \\
14 & $316.7 \pm 13.0$ & $0.291 \pm 0.043$ & $12.4 \pm 2.6$ \\
18 & $322.6 \pm 8.4$ & $0.317 \pm 0.006$ & $22.4 \pm 0.7$ \\
22 & $337.9 \pm 4.2$ & $0.360 \pm 0.004$ & $25.9 \pm 0.6$ \\
30 & $323.8 \pm 30.2$ & $0.377 \pm 0.084$ & $25.9 \pm 0.6$
\end{tabular}




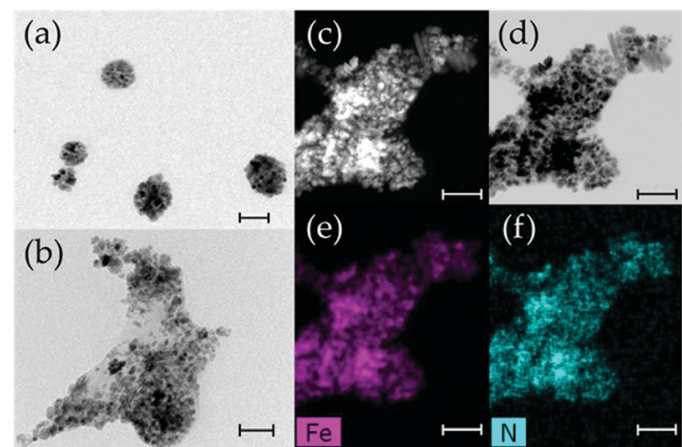

(g)

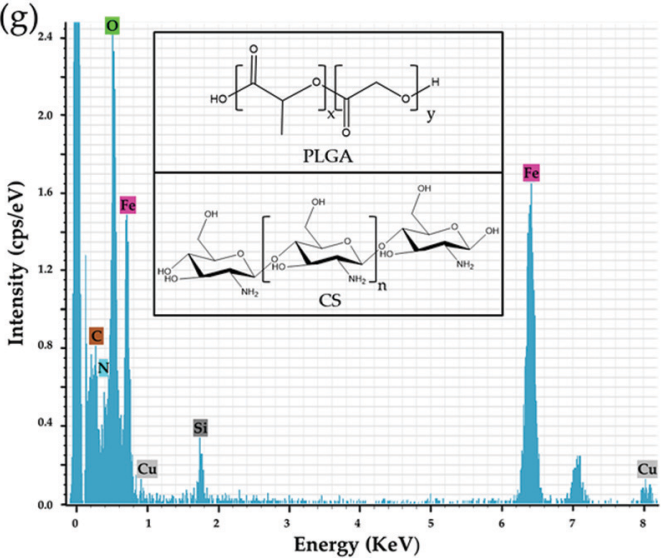

Fig. 1 (a) HRTEM of the $\left(\gamma-\mathrm{Fe}_{2} \mathrm{O}_{3} / \mathrm{PLGA}\right.$ ) (core/shell) particles. (b) HRTEM, (c) HAADF-STEM, and (d) ABF-STEM images of the $\left(\gamma-\mathrm{Fe}_{2} \mathrm{O}_{3} / \mathrm{PLGA}\right) / C S$ nanocomposites; EDX mapping analysis of the (e) Fe and ( $f$ ) $\mathrm{N}$ elements of the sample in (c and d); and (g) EDX spectra of the (core/shell)/shell NPs. Inset: Chemical structures of PLGA and CS. Bar lengths: $300 \mathrm{~nm}$ (a) and $100 \mathrm{~nm}(\mathrm{~b}, \mathrm{c}, \mathrm{d}, \mathrm{e}$, and f).

Given the different electrokinetic properties of PLGA-based ${ }^{41}$ and CS-based particles, ${ }^{37}$ electrophoresis was used to confirm qualitatively the coating efficiency of CS around the $\left(\gamma-\mathrm{Fe}_{2} \mathrm{O}_{3} / \mathrm{PLGA}\right)$ particles. The study was focused on the effect of $\mathrm{pH}$ on the surface electric charge ( $\zeta$ values) of the particles in the presence of $10^{-3} \mathrm{M}$ $\mathrm{KNO}_{3}$ (Fig. 2a). The negative surface charge of these $\gamma-\mathrm{Fe}_{2} \mathrm{O}_{3} / \mathrm{PLGA}$ particles may come from ionized weak acid groups, probably carboxylic-end groups. ${ }^{41,100}$ Under the experimental conditions, the decrease in absolute $\zeta$ values as $\mathrm{pH}$ became more acidic was associated to the neutralization of the negative regions of the polymer by adsorption of increasing amounts of $\mathrm{H}^{+}$. On the opposite, the increasingly negative $\zeta$ values may come from the increase in $\mathrm{OH}^{-}$ions in the dispersion media, which could tend to favour a gain in $\mathrm{H}^{+}$. In contrast, $\mathrm{CS}$ particles were characterized by positive $\zeta$ values for the whole $\mathrm{pH}$ range. The residual amino groups of $\mathrm{CS}$ could be responsible for this positive electric charge at the polymer-solution interface, ${ }^{37,101}$ despite the use of $\mathrm{SO}_{4}{ }^{2-}$ as a precipitant and regardless of the negative groups of the stabilizer Kolliphor ${ }^{\circledR} \mathrm{P}-188$ which could persist on the particle surface even after cleaning. Finally, Fig. 2a further demonstrates that the $\zeta-\mathrm{pH}$ trends of the $\left(\gamma-\mathrm{Fe}_{2} \mathrm{O}_{3} / \mathrm{PLGA}\right) / \mathrm{CS}$ NPs were dominated by the CS shell. This should be the result of the effective CS coating of $\left(\gamma-\mathrm{Fe}_{2} \mathrm{O}_{3}\right)$ PLGA) particles, leading to a (core/shell)/shell nanostructure
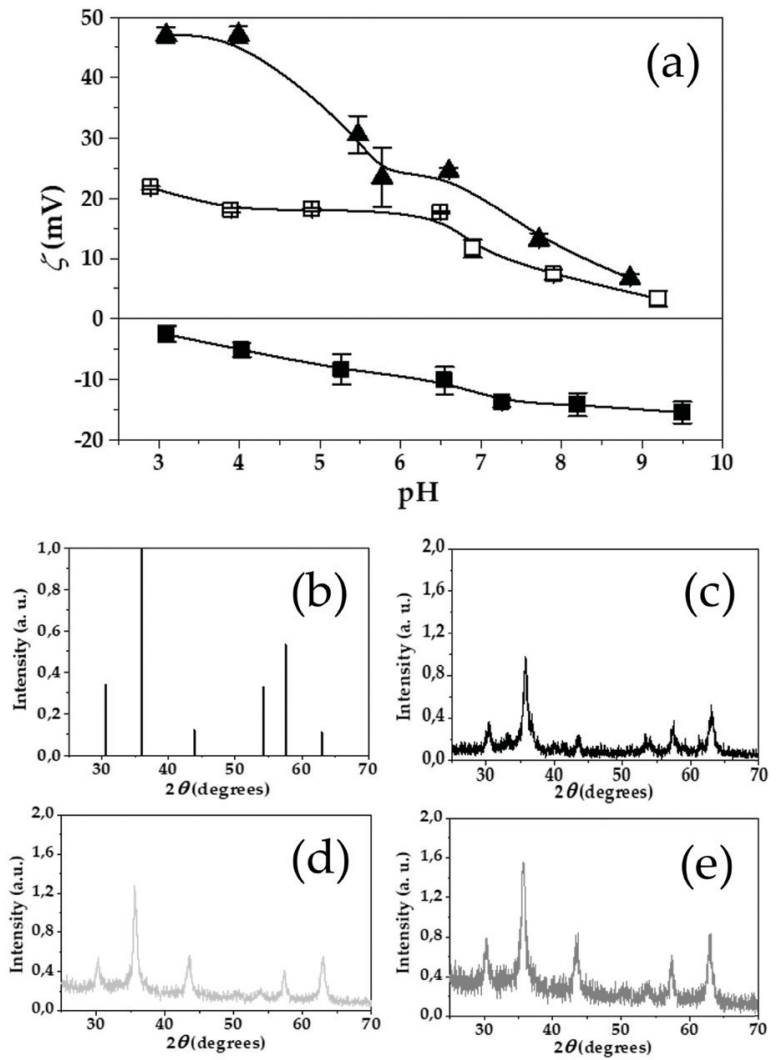

Fig. 2 (a) Zeta potential $(\zeta, \mathrm{mV})$ of $(\boldsymbol{\square}) \gamma-\mathrm{Fe}_{2} \mathrm{O}_{3} / \mathrm{PLGANPs}$ ( $\left.\mathbf{\Delta}\right) \mathrm{CS} N P s$, and ( $\square)\left(\gamma-\mathrm{Fe}_{2} \mathrm{O}_{3} / \mathrm{PLGA}\right) / \mathrm{CS}$ NPs as a function of $\mathrm{pH}$ in the presence of $1 \mathrm{mM}$ $\mathrm{KNO}_{3}$. Data are presented as mean value $\pm \mathrm{SD}(n=9)$. Lines are a guide to the eye and have no other significance. (b) American Society for Testing and Materials (ASTM) pattern for $\gamma-\mathrm{Fe}_{2} \mathrm{O}_{3}$. X-ray diffractograms of (c) $\gamma$ $\mathrm{Fe}_{2} \mathrm{O}_{3}$, (d) $\left(\gamma-\mathrm{Fe}_{2} \mathrm{O}_{3} / \mathrm{PLGA}\right)$, and (e) $\left(\gamma-\mathrm{Fe}_{2} \mathrm{O}_{3} / \mathrm{PLGA}\right) / \mathrm{CS}$ particles. The intensity is expressed in arbitrary units (a. u.).

which, from an electrokinetic point of view, is qualitatively similar to the CS particles.

Taking into account the data from the electrophoretic study, the mechanism of formation of the $\left(\gamma-\mathrm{Fe}_{2} \mathrm{O}_{3} / \mathrm{PLGA}\right) / \mathrm{CS}$ (core/ shell)/shell particles could be hypothesized. Attractive electrostatic interactions may take place under the acid condition characteristics of the aqueous medium where the nanocomposites were formed $(\mathrm{pH} \approx 3.3) \cdot{ }^{56,57}$ These interactions are expected to occur between the negatively charged $\gamma-\mathrm{Fe}_{2} \mathrm{O}_{3} / \mathrm{PLGA}$ particles and the positively charged CS matrix at this $\mathrm{pH}$ (see Fig. 2a), favouring the accumulation of CS onto the $\gamma-\mathrm{Fe}_{2} \mathrm{O}_{3} / \mathrm{PLGA}$ surface, and thus resulting in the formation of $\mathrm{a}\left(\gamma-\mathrm{Fe}_{2} \mathrm{O}_{3} / \mathrm{PLGA}\right) / \mathrm{CS}$ nanostructure.

Fig. 2b presents the American Society for Testing and Materials (ASTM) pattern of $\gamma-\mathrm{Fe}_{2} \mathrm{O}_{3}$ (ASTM No. 24-81). The X-ray diffraction patterns of $\gamma-\mathrm{Fe}_{2} \mathrm{O}_{3}$ (Fig. 2c), $\left(\gamma-\mathrm{Fe}_{2} \mathrm{O}_{3} / \mathrm{PLGA}\right)$ (Fig. 2d), and $\left(\gamma-\mathrm{Fe}_{2} \mathrm{O}_{3} / \mathrm{PLGA}\right) / \mathrm{CS}$ (Fig. 2e) particles coincided well with this pattern. This could be an indication of the mineralogical purity and high crystalline nature of the synthesized $\gamma-\mathrm{Fe}_{2} \mathrm{O}_{3}$ particles (responsible for the superparamagnetic behaviour and adequate responsiveness to magnetic fields), ${ }^{29}$ even upon complete coating by both the PLGA and CS matrices. 
$2 \theta$ values of the $\gamma-\mathrm{Fe}_{2} \mathrm{O}_{3}$ nuclei embedded in the (core/shell)/ shell NPs were $30.30^{\circ}, 35.64^{\circ}, 43.66^{\circ}, 54.10^{\circ}, 57.36^{\circ}$, and $63.04^{\circ}$, and they could be assigned to the (220), (311), (400), (422), (511), and (440) planes of these iron oxide particles, respectively. ${ }^{102-104}$

\section{Magnetic responsiveness}

The hysteresis cycle of the $\gamma-\mathrm{Fe}_{2} \mathrm{O}_{3} / \mathrm{PLGA}$ and $\left(\gamma-\mathrm{Fe}_{2} \mathrm{O}_{3} / \mathrm{PLGA}\right) / \mathrm{CS}$ NPs, plotted in Fig. 3a, characterized their field responsive behaviour. These particles apparently exhibited a soft magnetic character, given that the increasing and decreasing field ramps of the cycle were hardly discernible with the sensitivity of the instrument used. From the linear portions (low field) of the curves the initial susceptibility was calculated to be $\chi_{\mathrm{i}}=(0.071 \pm 0.009) \times 10^{-3}\left[\right.$ and $\left.(0.102 \pm 0.013) \times 10^{-3}\right] \mathrm{m}^{3} \mathrm{~kg}^{-1}$ and the saturation magnetization was $4.98 \pm 0.41$ (and $7.18 \pm 0.59$ ) $\mathrm{Am}^{2} \mathrm{~kg}^{-1}$ for the (core/shell)/shell (and core/shell $)$ NPs. The magnetic behaviour of the $\left(\gamma-\mathrm{Fe}_{2} \mathrm{O}_{3} / \mathrm{PLGA}\right) / \mathrm{CS}$ particles was quite similar to that of the $\gamma \mathrm{Fe}_{2} \mathrm{O}_{3} /$ PLGA particles, except that the CS shell reduced slightly the magnetization of the (core/shell)/shell sample. This could be the consequence, at equal mass of the sample analysed, of the smaller amount of $\gamma-\mathrm{Fe}_{2} \mathrm{O}_{3}$ nanocores contained inside the $\left(\gamma-\mathrm{Fe}_{2} \mathrm{O}_{3} / \mathrm{PLGA}\right) / \mathrm{CS}$ NPs in comparison to the sample of $\gamma-\mathrm{Fe}_{2} \mathrm{O}_{3} /$ PLGA particles.

In any case, the appropriate magnetic responsive behaviour of the (core/shell)/shell NPs was further qualitatively confirmed by optical microscope visualization of the colloid under

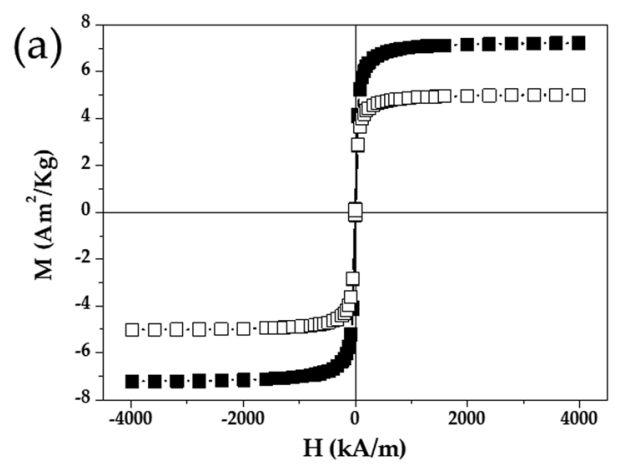

(b)

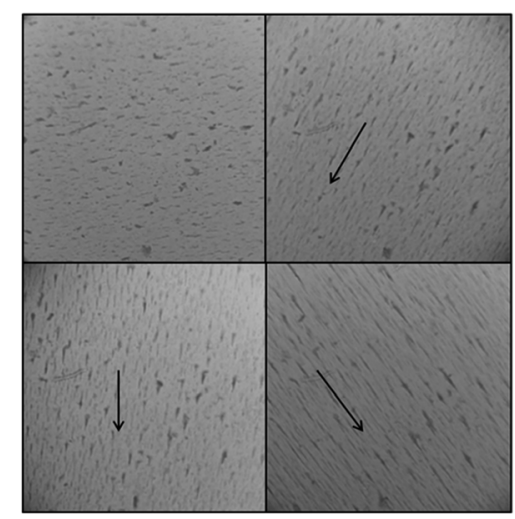

Fig. 3 (a) Hysteresis cycles of the $\gamma-\mathrm{Fe}_{2} \mathrm{O}_{3} / \mathrm{PLGA}(\mathbf{\square})$ and $\left(\gamma-\mathrm{Fe}_{2} \mathrm{O}_{3}\right)$ PLGA)/CS ( $\square$ ) particles; and (b) optical microphotographs (magnification $20 \times)$ of the (core/shell)/shell colloid $(0.1 \%, w / v)$ under the influence of a $0.4 \mathrm{~T}$ permanent magnet (in the direction of the arrow). exposure to a permanent magnet (Fig. 3b). The initially homogeneous aqueous dispersion of (core/shell)/shell particles changed markedly, and the formation of chainlike aggregates parallel to the field lines occurred. This could result from the notable contribution of the magnetic interaction over the DLVO colloidal interactions between the NPs (e.g. electrostatic van der Waals and hydration or acid-base). However, in vivo experiments should be done to clarify if this magnetic responsiveness could determine the accumulation of the $\left(\gamma-\mathrm{Fe}_{2} \mathrm{O}_{3} / \mathrm{PLGA}\right) / \mathrm{CS}$ particles at a targeted site.

Finally, a preliminary study on the potential use of the nanocomposites as MRI contrast agents was accomplished in vitro. $r_{1}$ and $r_{2}$ values for the $\gamma$ - $\mathrm{Fe}_{2} \mathrm{O}_{3}$ /PLGA particles were found to be 0.2 and $48.5 \mathrm{mM}^{-1} \times \mathrm{s}^{-1}$ (Fig. 4a), respectively, whereas 0.4 and $61.4 \mathrm{mM}^{-1} \times \mathrm{s}^{-1}$ were the $r_{1}$ and $r_{2}$ values for the $\left(\gamma-\mathrm{Fe}_{2} \mathrm{O}_{3} / \mathrm{PLGA}\right) / \mathrm{CS}$ nanocomposites (Fig. 4b), respectively. These relaxivities are comparable to those reported previously for similar iron oxide-based nanostructures ${ }^{77}$ and iron oxidebased MRI contrast agents, e.g. Sinerem ${ }^{\circledR}$ or Ferumoxytol. ${ }^{105-107}$ The $r_{2} / r_{1}$ ratios for $\gamma-\mathrm{Fe}_{2} \mathrm{O}_{3} / \mathrm{PLGA}$ and $\left(\gamma-\mathrm{Fe}_{2} \mathrm{O}_{3} / \mathrm{PLGA}\right) / \mathrm{CS}$ were 243.5 and 153.5, respectively, suggesting the potential application of these NPs as $T_{2}$ contrast agents. ${ }^{108,109}$

\section{In vitro haemocompatibility and cytotoxicity}

The contact of nanoparticulate systems with blood components may lead to adverse effects, e.g., platelet and complement system
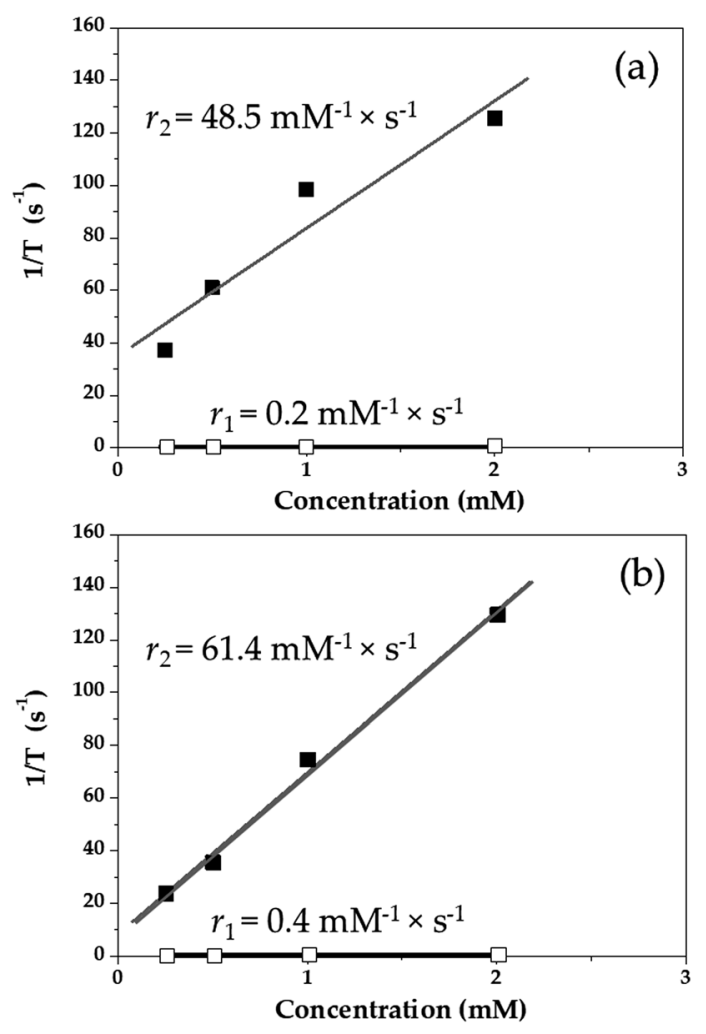

Fig. 4 Longitudinal $\left(\square, 1 / T_{1}, \mathrm{~s}^{-1}\right)$ and transverse $\left(\square, 1 / T_{2}, \mathrm{~s}^{-1}\right)$ relaxation rates as a function of the iron concentration (mM) in (a) $\gamma-\mathrm{Fe}_{2} \mathrm{O}_{3} / \mathrm{PLGA}$ and (b) $\left(\gamma-\mathrm{Fe}_{2} \mathrm{O}_{3} / \mathrm{PLGA}\right) / \mathrm{CS}$ NPs, measured at $1.44 \mathrm{~T}$. 
Table 2 In vitro blood compatibility of the $\gamma-\mathrm{Fe}_{2} \mathrm{O}_{3} / \mathrm{PLGA}$ and $\left(\gamma-\mathrm{Fe}_{2} \mathrm{O}_{3} / \mathrm{PLGA}\right) / \mathrm{CS}$ particles: haemolysis (\%), platelet activation (sP-selectin release, $\mathrm{ng} \mathrm{mL}^{-1}$ ), complement activation (C3a release: $\mathrm{C} 3 a$ desArg, $\mathrm{ng} \mathrm{mL}^{-1}$ ), and plasma recalcification time ( $T_{1 / 2}$ max, min). Experimental data are expressed as means $\pm \mathrm{SDs}$ of triplicate experiments $(n=3)$

\begin{tabular}{|c|c|c|c|c|c|c|c|}
\hline \multirow[b]{3}{*}{ Sample } & \multicolumn{4}{|c|}{ Haemolysis (\%) } & \multirow{3}{*}{$\begin{array}{l}\text { sP-selectin release } \\
\left(\mathrm{ng} \mathrm{mL} \mathrm{mL}^{-1}\right)\end{array}$} & \multirow{3}{*}{$\begin{array}{l}\text { C3a desArg } \\
\left({\left.\text { ng } \mathrm{mL}^{-1}\right)}\right.\end{array}$} & \multirow{3}{*}{$\begin{array}{l}T_{1 / 2 \max } \\
(\min )\end{array}$} \\
\hline & \multicolumn{4}{|c|}{ Incubation time } & & & \\
\hline & $2 \mathrm{~h}$ & $4 \mathrm{~h}$ & $8 \mathrm{~h}$ & $24 \mathrm{~h}$ & & & \\
\hline$\gamma-\mathrm{Fe}_{2} \mathrm{O}_{3} /$ PLGA NPs & $2.5 \pm 0.6$ & $2.5 \pm 0.9$ & $2.3 \pm 0.8$ & $2.5 \pm 0.5$ & $110 \pm 8$ & $305 \pm 9$ & $14.2 \pm 1.1$ \\
\hline$\left(\gamma-\mathrm{Fe}_{2} \mathrm{O}_{3} / \mathrm{PLGA}\right) / \mathrm{CS}$ NPs & $2.6 \pm 0.8$ & $2.9 \pm 0.4$ & $2.6 \pm 0.3$ & $2.8 \pm 0.6$ & $114 \pm 8$ & $306 \pm 10$ & $14.3 \pm 0.9$ \\
\hline Control (PBS solution) & 0 & 0 & 0 & 0 & $97 \pm 8$ & $295 \pm 7$ & $11.5 \pm 1.7$ \\
\hline
\end{tabular}

activation, and lysis of erythrocytes, ${ }^{29,85}$ being responsible for (i) thrombotic complications and production of anaphylatoxins, that may activate the immune system; ${ }^{85}$ and (ii) haemolytic crisis, that may determine renal damage and anaemia, ${ }^{85,110}$ respectively.

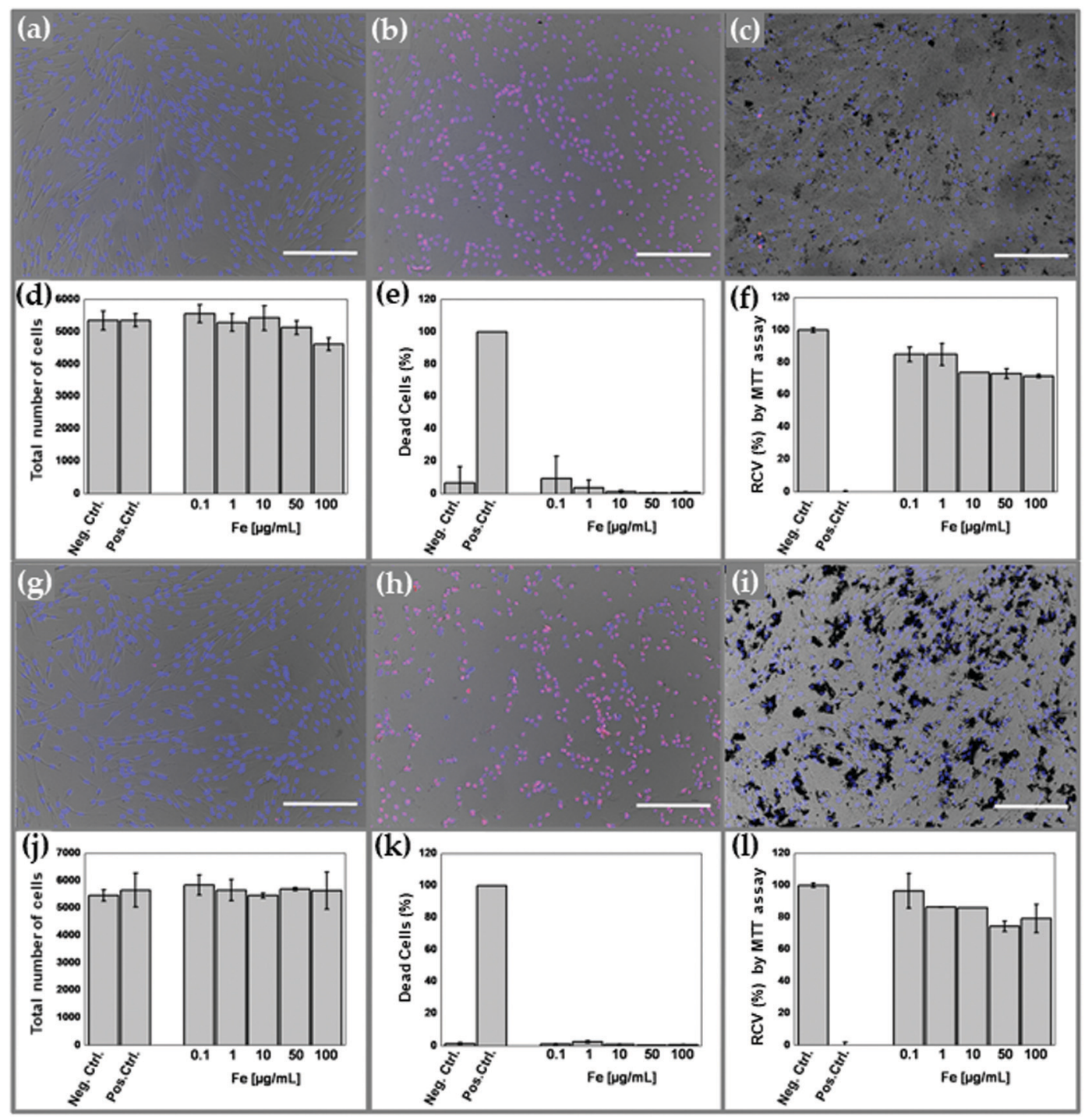

Fig. 5 Representative optical microscopy images of HFF-1 fibroblasts: (a) and (g) are negative controls for the $\gamma$ - $\mathrm{Fe}_{2} \mathrm{O}_{3} / \mathrm{PLGA}$ and $\left(\gamma-\mathrm{Fe}_{2} \mathrm{O}_{3} / \mathrm{PLGA}\right) / \mathrm{CS}$ particles, respectively; (b) and (h) are positive controls for the $\gamma-\mathrm{Fe}_{2} \mathrm{O}_{3} / \mathrm{PLGA}$ and $\left(\gamma-\mathrm{Fe}_{2} \mathrm{O}_{3} / \mathrm{PLGA}\right.$ )/CS NPs, respectively; and HFF-1 cells exposed to (c) $\gamma$ $\mathrm{Fe}_{2} \mathrm{O}_{3} /$ PLGA NPs $\left(100 \mu \mathrm{g} \mathrm{mL}{ }^{-1}\right.$ of iron) or (i) $\left(\gamma-\mathrm{Fe}_{2} \mathrm{O}_{3} / \mathrm{PLGA}\right) / \mathrm{CS} N P s\left(100 \mu \mathrm{g} \mathrm{mL}{ }^{-1}\right.$ of iron). These images show the merge of bright field (grey), DAPI (blue) and TO-PRO ${ }^{\mathbb{R}}-3$ iodide (red). Bar lengths: $100 \mu \mathrm{m}$. Total number of cells per well ( $\mathrm{d}$ and $\left.\mathrm{j}\right)$, dead cells (\%, e and $\mathrm{k}$ ), and relative cell viability (RCV, \%) by MTT assay ( $f$ and $l$ ) of HFF-1 fibroblasts, after contact with increasing concentrations ( 0.1 to $100 \mu \mathrm{gLL}^{-1}$ of iron) of $\gamma$ - $\mathrm{Fe}_{2} \mathrm{O}_{3} / \mathrm{PLGA} \mathrm{NPs}$ and $\left(\gamma-\mathrm{Fe}_{2} \mathrm{O}_{3}\right.$ ) PLGA)/CS NPS, respectively. 
Data from in vitro blood compatibility tests of $\gamma-\mathrm{Fe}_{2} \mathrm{O}_{3} /$ PLGA and $\left(\gamma-\mathrm{Fe}_{2} \mathrm{O}_{3} / \mathrm{PLGA}\right) / \mathrm{CS}$ NPs is compiled in Table 2 . The null effect on haemolysis (even after $24 \mathrm{~h}$ ), platelet activation, complement system activation, and plasma clotting time was defined. Therefore, these nanocomposites could be characterized by an appropriate in vivo safety margin, being suitable for parenteral administration. Similar results have been obtained in similar iron oxide-based nanosystems. ${ }^{39-41,87}$

The results from the cytotoxic evaluation of $\gamma-\mathrm{Fe}_{2} \mathrm{O}_{3} / \mathrm{PLGA}$ and $\left(\gamma-\mathrm{Fe}_{2} \mathrm{O}_{3} / \mathrm{PLGA}\right) / \mathrm{CS}$ particles in HFF-1 human foreskin fibroblast cells are presented in Fig. 5. It is observed how increasing concentrations, from 0.1 to $100 \mu \mathrm{g} \mathrm{mL}{ }^{-1}$ of iron, of both core/shell and (core/shell)/shell particles induced negligible toxicity in the HFF-1 cell line. In fact, they did not produce significant changes in cell morphology (Fig. 5c and i) and the total number of HFF- 1 cells (Fig. $5 \mathrm{~d}$ and j), at any of the concentrations investigated. Moreover, these NP concentrations did not generate a relevant increase in cell death (Fig. 5e and k). Finally, the RCV (\%) of HFF-1 cells remained $\geq 75 \%$, relative to negative controls, at any of the $\gamma-\mathrm{Fe}_{2} \mathrm{O}_{3} / \mathrm{PLGA}$ (Fig. 5f) and $\left(\gamma-\mathrm{Fe}_{2} \mathrm{O}_{3} / \mathrm{PLGA}\right) / \mathrm{CS}$ (Fig. 5l) concentrations analysed. According to ISO-10993-5, ${ }^{86}$ these values could be considered as reasonable and non-toxic.

\section{In vitro magnetic fluid hyperthermia}

Antitumour magnetic hyperthermia has proven to be more than a promising possibility against cancer. ${ }^{29,111-113}$ The heating capability of a (core/shell)/shell aqueous magnetofluid in a high frequency alternating electromagnetic gradient is depicted in Fig. 6a. The $\left(\gamma-\mathrm{Fe}_{2} \mathrm{O}_{3} / \mathrm{PLGA}\right) / \mathrm{CS}$ particles transformed into heaters, possibly owing to the oscillation of their magnetic moment and magnetic hysteresis losses..$^{29,114}$ As a consequence, the temperature of the magnetofluid rose from $25{ }^{\circ} \mathrm{C}$ to the minimum hyperthermia temperature $\left(\approx 42{ }^{\circ} \mathrm{C}\right.$, in $\approx 32$ min). If this temperature is kept constant for $\approx 30 \mathrm{~min}$, it has been described that a tumour mass can be destroyed. ${ }^{114,115}$ Then, the maximum temperature reached $\approx 46{ }^{\circ} \mathrm{C}$ after $\approx 50 \mathrm{~min}$, and remained at this temperature until the end of the experiment $(3 \mathrm{~h})$. Considering these results, an appropriate control over the temperature and heat flux of the magnetofluid could be postulated. This is a prerequisite for hyperthermia, particularly when healthy cells surrounding a solid tumour are damaged when temperature reaches $>48{ }^{\circ} \mathrm{C}^{29,116,117}$

Fig. $6 \mathrm{~b}$ compiles the results from the evaluation of the hyperthermic efficacy of the $\left(\gamma-\mathrm{Fe}_{2} \mathrm{O}_{3} / \mathrm{PLGA}\right) / \mathrm{CS}$ NPs against T-84 cells. Experimental data proved that compared to controls the (core/shell)/shell NPs in a high frequency alternating electromagnetic gradient can significantly reduce cell viability (up to $\approx 39 \%$, group 1 ) ( $p<0.05$ ), thus being postulated to be a promising nanotool for antitumour magnetic hyperthermia. Oppositely, when used alone, neither the particles (group 2) nor the field (group 3) could be considered of any use against T-84 cells. Finally, in vivo magnetic fluid hyperthermia data will help in defining clearly the antitumor effect of the nanostructures.
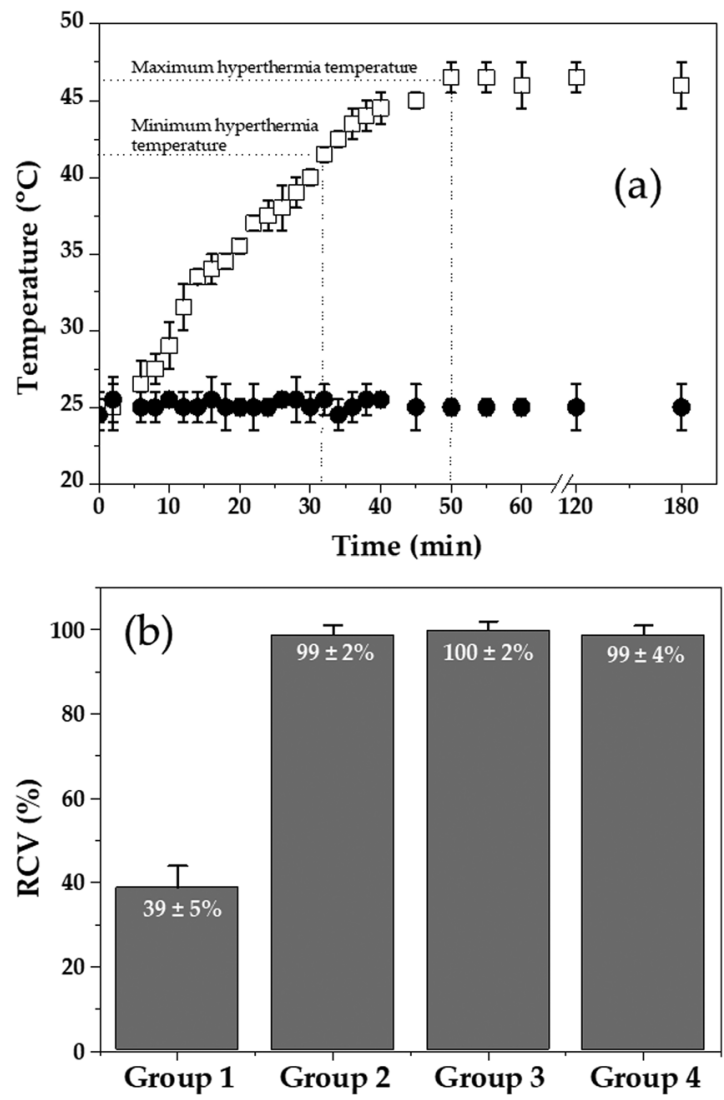

Fig. 6 (a) Heating curve of an aqueous dispersion of $\left(\gamma-\mathrm{Fe}_{2} \mathrm{O}_{3} / \mathrm{PLGA}\right) / \mathrm{CS}$ nanocomposites $\left(\square, 10 \mathrm{mg} \mathrm{mL}^{-1}\right)$ exposed to a high frequency oscillating electromagnetic gradient $\left(250 \mathrm{kHz}, 4 \mathrm{kA} \mathrm{m}^{-1}\right)$, in comparison to data from a control (i.e. water, - ). (b) In vitro hyperthermic efficacy of the magnetic (core/shell)/shell NPs on T-84 relative cell viability (RCV, \%). Experimental groups are cells incubated in the presence of NPs $(0.4 \%, w / w)$ with application of the alternating magnetic field $\left(250 \mathrm{kHz}, 4 \mathrm{kA} \mathrm{m}^{-1}\right.$ ) (group 1), or without application of the alternating magnetic field (control group 2); or cells incubated in the absence of NPs with application of the alternating magnetic field $\left(250 \mathrm{kHz}, 4 \mathrm{kA} \mathrm{m}^{-1}\right.$ ) (control group 3), or without application of the alternating magnetic field (control group 4). Experimental data are expressed as means \pm SDs of triplicate experiments $(n=3)$.

\section{In vivo MRI}

Short-term pharmacokinetics of $\gamma-\mathrm{Fe}_{2} \mathrm{O}_{3} / \mathrm{PLGA}$ (core/shell) NPs after intravenous injection in Balb/c mice was followed by dynamic MRI (Fig. 7). Rapid particle uptake by the liver and spleen was detected (Fig. 7a and b, respectively), with a fast signal increase of $\approx 30 \%$ in $\approx 5 \mathrm{~min}$ in the liver, whereas in the spleen the increment was slightly more progressive. On the opposite, NP retention by kidneys could be considered almost negligible, given that the initial increase in the relative signal intensity (\%) was followed by a fast decrease to baseline (Fig. 7c). No change in the relative signal intensity (\%) was observed in muscles. These results suggest rapid recognition of the core/shell particles by the MPS, likely leading to rapid clearance from the bloodstream by Kupffer cells and splenic macrophages.

The in vivo fate of the $\gamma-\mathrm{Fe}_{2} \mathrm{O}_{3} /$ PLGA NPs was further evaluated qualitatively by $T_{2}$-weighted $\mathrm{MR}$ images (Fig. $7 \mathrm{~d}-\mathrm{f}$ ) and 

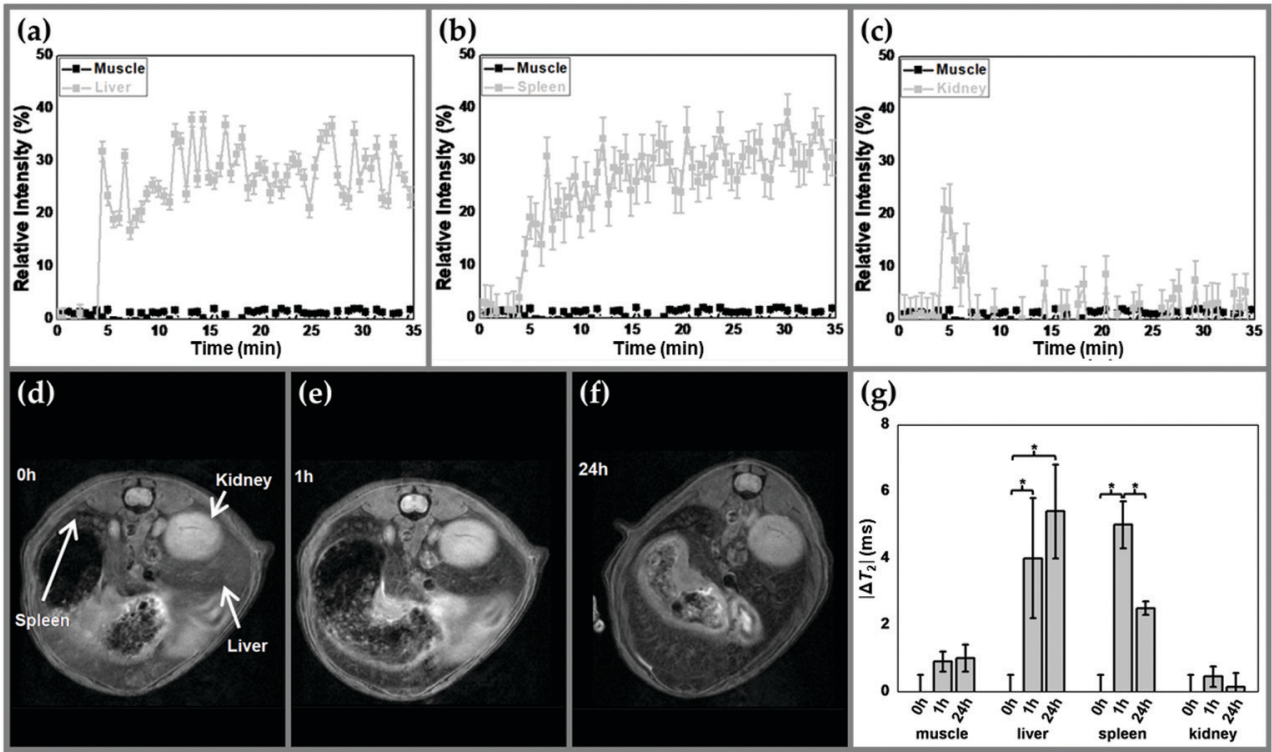

Fig. 7 In vivo time courses of $\gamma-\mathrm{Fe}_{2} \mathrm{O}_{3} /$ PLGA NPs after intravenous injection in Balb/c mice: (a) liver (grey) and muscle (black); (b) spleen (grey) and muscle (black); and (c) kidney (grey) and muscle (black). Representative $T_{2}$-weighted MR images of the kidney, spleen, and liver after the injection of the NPs, at the experimental times: (d) $0 \mathrm{~h}$, (e) $1 \mathrm{~h}$, and (f) $24 \mathrm{~h}$. (g) Absolute values of $\Delta T_{2}$ (ms) as a function of time (hours) of muscle, liver, spleen and kidney after the injection of the core/shell NPs. Experimental data are expressed as means \pm SDs of triplicate experiments $(n=3)$. The statistical test was significant for data with * $(p<0.05)$.

quantitatively by $T_{2}$-mapping (Fig. $7 \mathrm{~g}$ ) up to $24 \mathrm{~h}$. Liver and spleen images showed clear hypo-intensity areas at 1 and $24 \mathrm{~h}$ postinjection (Fig. 7e and $\mathrm{f}$, respectively). In contrast, significant changes in the kidneys were not observed. Furthermore, a significant decrease in $T_{2}$ for the liver $\left(\Delta T_{2} \approx 4 \mathrm{~ms}\right)$ and spleen $\left(\Delta T_{2} \approx 5 \mathrm{~ms}\right)$ can be identified in Fig. $7 \mathrm{~g}(p<0.05)$ at $1 \mathrm{~h}$ postinjection. By the end of the study $(t=24 \mathrm{~h})$, the absolute value of $\Delta T_{2}$ was increased further to $\approx 5.4 \mathrm{~ms}$ for the liver
( $p<0.05$ ), while being partially recovered in the spleen ( $\approx 2.2 \mathrm{~ms}, p<0.05$ ). Finally, significant changes in $\Delta T_{2}$ were not detected in kidneys or muscles during the study.

The biodistribution of the $\left(\gamma-\mathrm{Fe}_{2} \mathrm{O}_{3} / \mathrm{PLGA}\right) / \mathrm{CS}$ particles was found to be quite different from what was described for the $\gamma-\mathrm{Fe}_{2} \mathrm{O}_{3} /$ PLGA NPs. The uptake of these (core/shell)/shell nanoplatforms by the liver (Fig. 8a) was lower than that observed for the $\gamma-\mathrm{Fe}_{2} \mathrm{O}_{3} / \mathrm{PLGA}$ particles (Fig. 7a), given that increments in

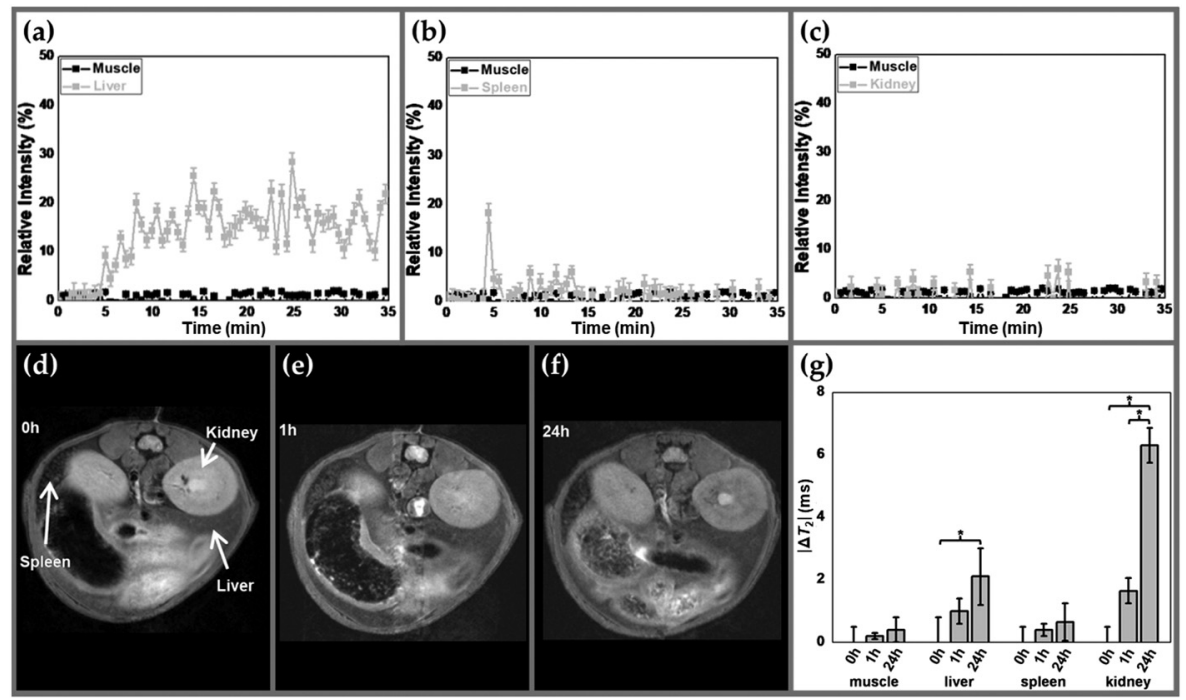

Fig. 8 In vivo time courses of $\left(\gamma-\mathrm{Fe}_{2} \mathrm{O}_{3} / \mathrm{PLGA}\right) / \mathrm{CS}$ nanocomposites after intravenous injection in Balb/c mice: (a) liver (grey) and muscle (black); (b) spleen (grey) and muscle (black); and (c) kidney (grey) and muscle (black). Representative $T_{2}$-weighted MR images of the kidney, spleen, and liver after the injection of the NPs, at the experimental times: (d) $0 \mathrm{~h}$, (e) $1 \mathrm{~h}$, and (f) $24 \mathrm{~h}$. (g) Absolute values of $\Delta T_{2}$ (ms) as a function of time (hours) of muscle, liver, spleen and kidney after the injection of the (core/shell)/shell NPs. Experimental data are expressed as means \pm SDs of triplicate experiments $(n=3)$. The statistical test was significant for data with * $(p<0.05)$. 


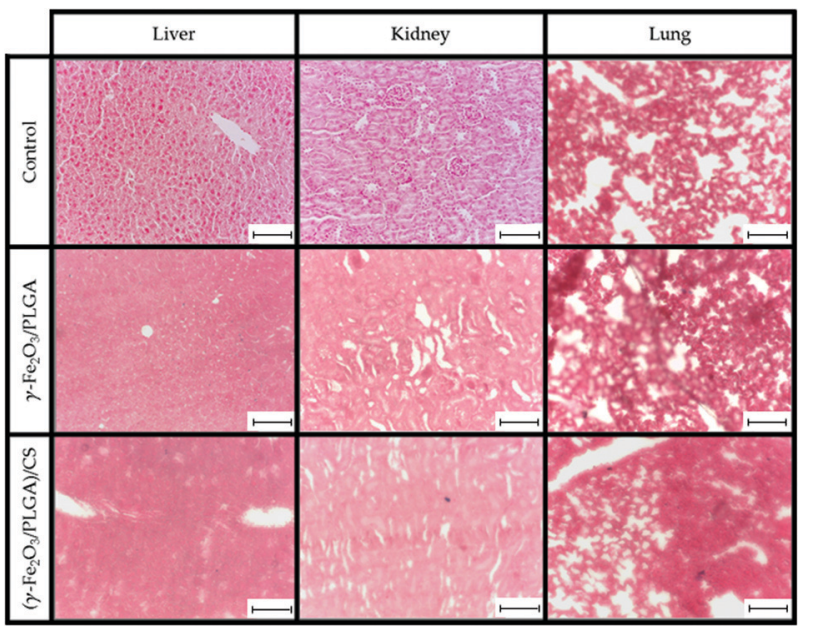

Fig. 9 PB staining of representative histological sections of control liver, kidney and lung, and liver, kidney and lung at $24 \mathrm{~h}$ post-intravenous injection of $\gamma-\mathrm{Fe}_{2} \mathrm{O}_{3} /$ PLGA NPs and $\left(\gamma-\mathrm{Fe}_{2} \mathrm{O}_{3} / \mathrm{PLGA}\right) / \mathrm{CS}$ nanocomposites. Bar lengths: $100 \mu \mathrm{m}$.

the relative signal intensity (\%) values were a little smaller, even though the $r_{2}$ value of the former was $\approx 30 \%$ higher and the amount injected was the same in both cases.

CS coating onto the (core/shell) nanostructure further favoured an almost null uptake of the $\left(\gamma-\mathrm{Fe}_{2} \mathrm{O}_{3} / \mathrm{PLGA}\right) / \mathrm{CS}$ NPs by the spleen (Fig. 8b). In view of these results, it could be postulated that CS provided adequate stealth properties to the nanocomposite,$^{52-55}$ leading to prolonged blood circulation times (a relevant attribute for biomedical applications). Similarly to $\gamma-\mathrm{Fe}_{2} \mathrm{O}_{3} / \mathrm{PLGA}$ particles, no change in the relative signal intensity (\%) was observed in kidneys and muscles after intravenous injection of the (core/shell)/shell NPs (Fig. 8c).

In vivo distribution data confirmed these findings (Fig. 8d-g). For instance, increments in the absolute value of $\Delta T_{2}$ for liver induced by the $\left(\gamma-\mathrm{Fe}_{2} \mathrm{O}_{3} / \mathrm{PLGA}\right) / \mathrm{CS}$ NPs (up to $\approx 1.9 \mathrm{~ms}, p<0.05$, Fig. $8 \mathrm{~g}$ ) were found to be smaller than those induced by the $\gamma-\mathrm{Fe}_{2} \mathrm{O}_{3} /$ PLGA particles (Fig. 7g). These data may ratify that the uptake of the (core/shell)/shell NPs by the liver was lower than that observed for the $\gamma-\mathrm{Fe}_{2} \mathrm{O}_{3} /$ PLGA particles. Quantitative $T_{2}$-mapping confirmed the negligible uptake of the (core/shell)/ shell nanostructure by the spleen and muscles found in Fig. 8b, which may probably the consequence of an almost null interaction of the particles with splenic macrophages. Finally, significant changes in the absolute value of $\Delta T_{2}$ were observed for the kidneys $(p<0.05)$, reaching up to $\approx 6.1 \mathrm{~ms}$ at $24 \mathrm{~h}$ postinjection.

Despite these promising results highlighting the stealthiness of the $\left(\gamma-\mathrm{Fe}_{2} \mathrm{O}_{3} / \mathrm{PLGA}\right) / \mathrm{CS}$ NPs, experiments in tumourbearing mice are needed to better define if magnetically guided targeting can make possible the selective accumulation of the (core/shell)/shell particles in the tumour mass.

\section{Ex vivo histology evaluation of iron deposits and toxicity assessment}

PB staining of liver, kidney and lung tissues at $24 \mathrm{~h}$ postinjection of $\gamma-\mathrm{Fe}_{2} \mathrm{O}_{3} / \mathrm{PLGA}$ NPs and $\left(\gamma-\mathrm{Fe}_{2} \mathrm{O}_{3} / \mathrm{PLGA}\right) / \mathrm{CS}$ in Balb/c mice is compiled in Fig. 9. Iron deposits in the liver, mainly in Kupffer cells, were observed after administration of the core/ shell particles, while iron deposits were not detected in kidneys and lungs. With respect to the (core/shell)/shell nanocomposites, iron deposits were found not only in the liver, but also in kidneys and lungs. All these findings were in agreement with the MRI results (see Fig. 7 and 8). This evaluation may support the hypothesis on the advantageous use of CS if longcirculating properties are intended for a nanoparticulate system. ${ }^{52-55}$ In addition, surface modification with CS has been described to favour a more extensive biodistribution, e.g. targeting lung tissue. ${ }^{118}$

In order to further evaluate the potential toxicity of $\gamma-\mathrm{Fe}_{2} \mathrm{O}_{3} /$ PLGA NPs and $\left(\gamma-\mathrm{Fe}_{2} \mathrm{O}_{3} / \mathrm{PLGA}\right) / \mathrm{CS}$, H\&E staining of liver, kidney, spleen, lungs and heart tissues at $24 \mathrm{~h}$ postinjection

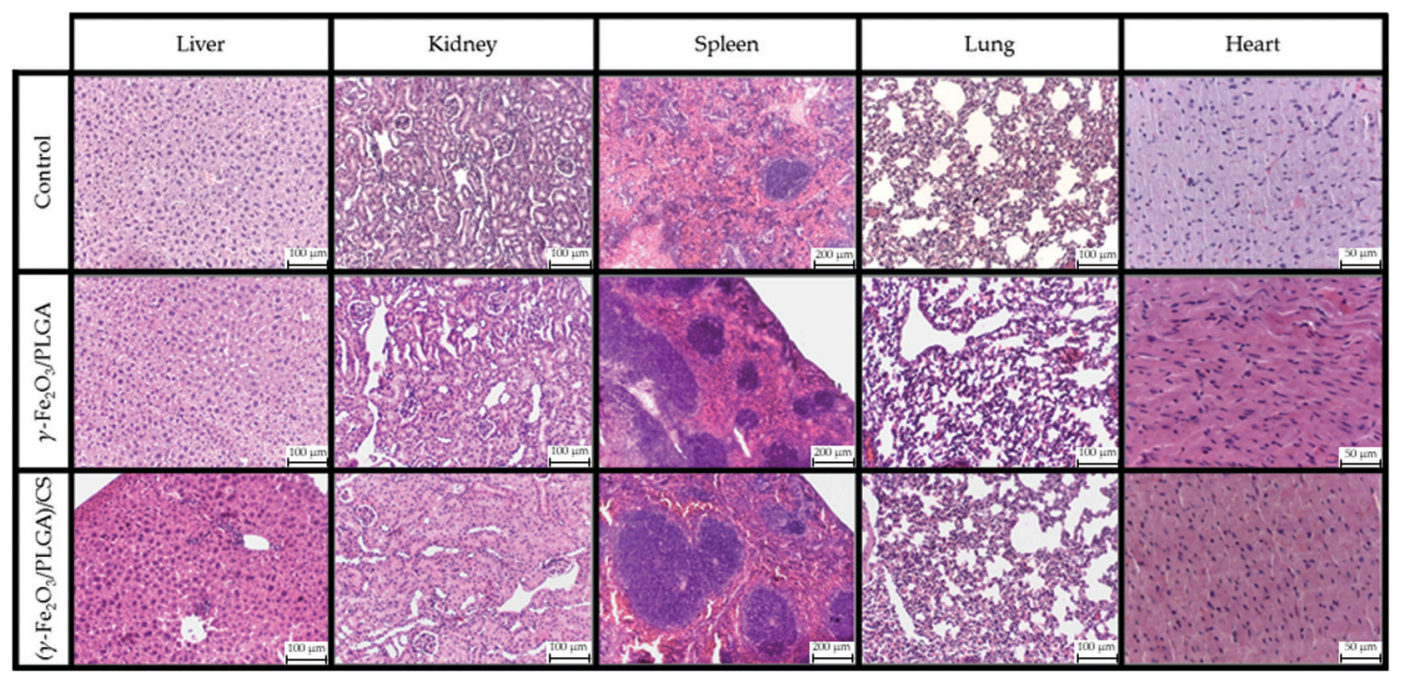

Fig. 10 H\&E staining of representative histological sections of control liver, kidney, spleen, lung and heart, and liver, kidney, spleen, lung and heart at $24 \mathrm{~h}$ post-intravenous injection of $\gamma-\mathrm{Fe}_{2} \mathrm{O}_{3} / \mathrm{PLGA} N P S$ and $\left(\gamma-\mathrm{Fe}_{2} \mathrm{O}_{3} / \mathrm{PLGA}\right) / \mathrm{CS}$ nanocomposites. 
in Balb/c mice was accomplished (Fig. 10). Vacuolated swelling of the cytoplasm of hepatocytes, a common indicator of liver injury, was not found in liver sections. Normal tubular brush borders and glomeruli (including their surrounding Bowman's capsule) were identified in the kidneys. No signs of toxicity were found also in the spleen, lungs, and heart, independently of the type of nanoparticulate system $\left[\gamma-\mathrm{Fe}_{2} \mathrm{O}_{3} / \mathrm{PLGA}\right.$ NPs or $\left(\gamma-\mathrm{Fe}_{2} \mathrm{O}_{3}\right)$ PLGA)/CS particles].

Combining these data with the results coming from the in vitro haemocompatibility and cytotoxicity tests (see Section In vitro haemocompatibility and cytotoxicity), it could be concluded that the nanocomposites present appropriate biocompatibility and safety for biomedical use.

\section{Conclusions}

A methodology has been described for the reproducible formulation of $\left(\gamma-\mathrm{Fe}_{2} \mathrm{O}_{3} / \mathrm{PLGA}\right) / \mathrm{CS}$ NPs $(\approx 325 \mathrm{~nm}$ in size, production performance $\approx 45 \%$ ). This (core/shell)/shell nanostructure was confirmed by electron microscopy and EDX analysis, and by investigation of the electrokinetic properties. Short-term stability (up to one month) was demonstrated by size and surface electric charge determinations. Crystallinity of the $\gamma-\mathrm{Fe}_{2} \mathrm{O}_{3}$ nanocores embedded in the polymer matrix was demonstrated by X-ray diffraction analysis, with this characteristic probably being responsible for the adequate magnetic responsiveness of the nanocomposite (demonstrated in vitro). In vitro evaluations supported the idea of a potential use of the $\left(\gamma-\mathrm{Fe}_{2} \mathrm{O}_{3} / \mathrm{PLGA}\right) / \mathrm{CS}$ particles as $T_{2}$ contrast agents and in antitumour magnetic hyperthermia. Ex vivo toxicity assessments and in vitro blood compatibility and cytotoxicity tests postulated the appropriate biocompatibility and safety of the particles for biomedical use. Finally, in vivo MRI studies and ex vivo histology determination of iron deposits reinforced the hypothesis on the advantageous use of CS in providing stealth properties to the nanosystem that may help in retarding the recognition by the MPS. Taking together, these biocompatible and long-circulating (core/shell)/shell nanostructures may constitute a potential candidate for theranostic applications (biomedical imaging and hyperthermia) against cancer. Additional experiments in tumour-bearing mice will help in defining if magnetically guided targeting could make possible the selective accumulation of the (core/shell)/shell particles in the tumour mass and the therapeutic effectiveness of this nanoplatform in cancer hyperthermia therapy.

\section{Author contributions}

Conceived and designed the experiments: FF-A, CC, MLG-M, JLA. Performed the experiments: FF-A, GG-G, CC. Analysed the data: FF-A, GG-G, CC, JLA. Contributed reagents/materials/ analysis tools: MLG-M, JLA. Wrote the paper: FF-A, CC, MLGM, JLA.

\section{Conflicts of interest}

The authors declare that they have no competing interests.

\section{Acknowledgements}

Financial support was provided by grants from the Instituto de Salud Carlos III (ISCIII) (project PI19/01478) (FEDER); Programa Operativo FEDER de Andalucía 2014-2020, Junta de Andalucía (project I + D + i A1-FQM-341-UGR18); and Ministerio de Economía y Competitividad (Spain, CTQ2017-86655-R to María Luisa García-Martín). The authors also thank the Nanoimaging Unit, unit U28 of NanBiosis - Infraestructuras Científico-Tecnológicas Singulares (ICTS) (Spain), where the relaxivity and MRI experiments were performed.

\section{Notes and references}

1 B. Clares, M. A. Ruiz, V. Gallardo and J. L. Arias, Drug delivery to inflammation based on nanoparticles surface decorated with biomolecules, Curr. Med. Chem., 2012, 19, 3203-3211.

2 A. Wicki, D. Witzigmann, V. Balasubramanian and J. Huwyler, Nanomedicine in cancer therapy: challenges, opportunities, and clinical applications, J. Controlled Release, 2015, 200, 138-157.

3 M. M. El-Hammadi and J. L. Arias, Nano-sized platforms for vaginal drug delivery, Curr. Pharm. Des., 2015, 21, 1633-1644.

4 J. Shi, P. W. Kantoff, R. Wooster and O. C. Farokhzad, Cancer nanomedicine: progress, challenges and opportunities, Nat. Rev. Cancer, 2017, 17, 20-37.

5 Z. Li, S. Tan, S. Li, Q. Shen and K. Wang, Cancer drug delivery in the nano era: an overview and perspectives (review), Oncol. Rep, 2017, 38, 611-624.

6 N. Amreddy, A. Babu, R. Muralidharan, J. Panneerselvam, A. Srivastava, R. Ahmed, M. Mehta, A. Munshi and R. Ramesh, Recent advances in nanoparticle-based cancer drug and gene delivery, Adv. Cancer Res., 2018, 137, 115-170.

7 J. L. Arias, Drug targeting strategies in cancer treatment: an overview, Mini-Rev. Med. Chem., 2011, 11, 1-17.

8 L. Kotelevets, E. Chastre, D. Desmaële and P. Couvreur, Nanotechnologies for the treatment of colon cancer: from old drugs to new hope, Int. J. Pharm., 2016, 514, 24-40.

9 Y. Zhang, M. Li, X. Gao, Y. Chen and T. Liu, Nanotechnology in cancer diagnosis: progress, challenges and opportunities, J. Hematol. Oncol., 2019, 12, 137.

10 B. J. Stephen, S. Suchanti, R. Mishra and A. Singh, Cancer nanotechnology in medicine: a promising approach for cancer detection and diagnosis, Crit. Rev. Ther. Drug Carrier Syst., 2020, 37, 375-405.

11 A. Sohail, Z. Ahmad, O. A. Bég, S. Arshad and L. Sherin, A review on hyperthermia via nanoparticle-mediated therapy, Bull. Cancer, 2017, 104, 452-461. 
12 J. K. Kang, J. C. Kim, Y. Shin, S. M. Han, W. R. Won, J. Her, J. Y. Park and K. T. Oh, Principles and applications of nanomaterial-based hyperthermia in cancer therapy, Arch. Pharmacal Res., 2020, 43, 46-57.

13 P. García Calavia, G. Bruce, L. Pérez-García and D. A. Russell, Photosensitiser-gold nanoparticle conjugates for photodynamic therapy of cancer, Photochem. Photobiol. Sci., 2018, 17, 1534-1552.

14 S. Kwiatkowski, B. Knap, D. Przystupski, J. Saczko, E. Kędzierska, K. Knap-Czop, J. Kotlińska, O. Michel, K. Kotowski and J. Kulbacka, Photodynamic therapy mechanisms, photosensitizers and combinations, Biomed. Pharmacother., 2018, 106, 1098-1107.

15 X. Hou, Y. Tao, Y. Pang, X. Li, G. Jiang and Y. Liu, Nanoparticle-based photothermal and photodynamic immunotherapy for tumor treatment, Int. J. Cancer, 2018, 143, 3050-3060.

16 Y. Liu, B. M. Crawford and T. Vo-Dinh, Gold nanoparticlesmediated photothermal therapy and immunotherapy, Immunotherapy, 2018, 10, 1175-1188.

17 M. M. El-Hammadi and J. L. Arias, An update on liposomes in drug delivery: a patent review (2014-2018), Expert Opin. Ther. Pat., 2019, 29, 891-907.

18 R. Brusini, M. Varna and P. Couvreur, Advanced nanomedicines for the treatment of inflammatory diseases, $A d v$. Drug Delivery Rev., 2020, 157, 161-178.

19 A. A. Sebak, B. M. El-Shenawy, S. El-Safy and M. El-Shazly, From passive targeting to personalized nanomedicine: multidimensional insights on nanoparticles' interaction with the tumor microenvironment, Curr. Pharm. Biotechnol., 2020, DOI: 10.2174/1389201021666201211103856.

20 K. R. Gajbhiye, A. Pawar, K. R. Mahadik and V. Gajbhiye, PEGylated nanocarriers: A promising tool for targeted delivery to the brain, Colloids Surf., B, 2020, 187, 110770.

21 M. M. El-Hammadi, A. V. Delgado, C. Melguizo, J. C. Prados and J. L. Arias, Folic acid-decorated and PEGylated PLGA nanoparticles for improving the antitumour activity of 5-fluorouracil, Int. J. Pharm., 2017, 516, 61-70.

22 K. S. Cho, S. J. Hong, M. H. Ahn, S. Pal, P. H. Choung, J. Sangshetti and R. B. Arote, Targeted delivery of siRNA therapeutics using ligand mediated biodegradable polymeric nanocarriers, Curr. Pharm. Des., 2018, 24, 1788-1800.

23 A. Baker, M. S. Khan, M. Z. Iqbal and M. S. Khan, Tumortargeted drug delivery by nanocomposites, Curr. Drug Metab., 2020, 21, 599-613.

24 J. Majumder and T. Minko, Multifunctional and stimuliresponsive nanocarriers for targeted therapeutic delivery, Expert Opin. Drug Delivery, 2020, 1, 23.

25 H. Li, J. Sun, H. Zhu, H. Wu, H. Zhang, Z. Gu and K. Luo, Recent advances in development of dendritic polymerbased nanomedicines for cancer diagnosis, Wiley Interdiscip. Rev.: Nanomed. Nanobiotechnol., 2020, e1670.

26 J. L. Arias, Liposomes in drug delivery: a patent review (2007present), Expert Opin. Ther. Pat., 2013, 23, 1399-1414.

27 V. Jain, H. Kumar, H. V. Anod, P. Chand, N. V. Gupta, S. Dey and S. S. Kesharwani, A review of nanotechnology-based approaches for breast cancer and triple-negative breast cancer, J. Controlled Release, 2020, 326, 628-647.

28 J. D. Durán, J. L. Arias, V. Gallardo and A. V. Delgado, Magnetic colloids as drug vehicles, J. Pharm. Sci., 2008, 97, 2948-2983.

29 L. H. Reddy, J. L. Arias, J. Nicolas and P. Couvreur, Magnetic nanoparticles: design and characterization, toxicity and biocompatibility, pharmaceutical and biomedical applications, Chem. Rev., 2012, 112, 5818-5878.

30 M. M. El-Hammadi and J. L. Arias, Iron oxide-based multifunctional nanoparticulate systems for biomedical applications: a patent review (2008 - present), Expert Opin. Ther. Pat., 2015, 25, 691-709.

31 P. Das, M. Colombo and D. Prosperi, Recent advances in magnetic fluid hyperthermia for cancer therapy, Colloids Surf., B, 2019, 174, 42-55.

32 T. L. Kalber, K. L. Ordidge, P. Southern, M. R. Loebinger, P. G. Kyrtatos, Q. A. Pankhurst, M. F. Lythgoe and S. M. Janes, Hyperthermia treatment of tumors by mesenchymal stem cell-delivered superparamagnetic iron oxide nanoparticles, Int. J. Nanomed., 2016, 11, 1973-1983.

33 Z. Bakhtiary, A. A. Saei, M. J. Hajipour, M. Raoufi, O. Vermesh and M. Mahmoudi, Targeted superparamagnetic iron oxide nanoparticles for early detection of cancer: Possibilities and challenges, Nanomedicine, 2016, 12, 287-307.

34 D. J. J. M. de Gouw, M. C. Maas, C. Slagt, J. Mühling, A. Nakamoto, B. R. Klarenbeek, C. Rosman, J. J. Hermans and T. W. J. Scheenen, Controlled mechanical ventilation to detect regional lymph node metastases in esophageal cancer using USPIO-enhanced MRI; comparison of image quality, Magn. Reson. Imaging, 2020, 74, 258-265.

$35 \mathrm{~J}$. L. Arias, Advanced methodologies to formulate nanotheragnostic agents for combined drug delivery and imaging, Expert. Opin. Drug Delivery, 2011, 8, 1589-1608.

36 S. M. Dadfar, K. Roemhild, N. I. Drude, S. von Stillfried, R. Knüchel, F. Kiessling and T. Lammers, Iron oxide nanoparticles: diagnostic, therapeutic and theranostic applications, Adv. Drug Delivery Rev., 2019, 138, 302-325.

37 J. L. Arias, L. H. Reddy and P. Couvreur, $\mathrm{Fe}_{3} \mathrm{O}_{4} /$ chitosan nanocomposite for magnetic drug targeting to cancer, J. Mater. Chem., 2012, 22, 7622-7632.

38 G. García-García, F. Fernández-Álvarez, L. Cabeza, A. V. Delgado, C. Melguizo, J. C. Prados and J. L. Arias,

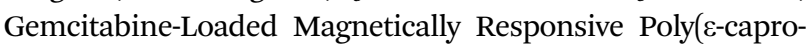
lactone) Nanoparticles against Breast Cancer, Polymers, 2020, 12, 2790.

39 M. Muñoz de Escalona, E. Sáez-Fernández, J. C. Prados, C. Melguizo and J. L. Arias, Magnetic solid lipid nanoparticles in hyperthermia against colon cancer, Int. J. Pharm., 2016, 504, 11-19.

40 C. Lorente, L. Cabeza, B. Clares, R. Ortiz, L. Halbaut, A. V. Delgado, G. Perazzoli, J. Prados, J. L. Arias and C. Melguizo, Formulation and in vitro evaluation of magnetoliposomes as a potential nanotool in colorectal cancer therapy, Colloids Surf., B, 2018, 171, 553-565. 
41 B. Pérez-Artacho, V. Gallardo, M. A. Ruiz and J. L. Arias, Maghemite/poly(d,l-lactide-co-glycolyde) composite nanoplatform for therapeutic applications, J. Nanopart. Res., 2012, 14, 768.

42 Y. N. Cui, Q. X. Xu, P. Davoodi, D. P. Wang and C. H. Wang, Enhanced intracellular delivery and controlled drug release of magnetic PLGA nanoparticles modified with transferrin, Acta Pharmacol. Sin., 2017, 38, 943-953.

43 H. A. Chen, Y. H. Ma, T. Y. Hsu and J. P. Chen, Preparation of peptide and recombinant tissue plasminogen activator conjugated poly(lactic-co-glycolic acid) (PLGA) magnetic nanoparticles for dual targeted thrombolytic therapy, Int. J. Mol. Sci., 2020, 21, 2690.

44 G. K. Jain, S. A. Pathan, S. Akhter, N. Ahmad, N. Jain, S. Talegaonkar, R. K. Khar and F. J. Ahmad, Mechanistic study of hydrolytic erosion and drug release behaviour of PLGA nanoparticles: influence of chitosan, Polym. Degrad. Stab., 2010, 95, 2360-2366.

45 R. Domínguez-Ríos, D. R. Sánchez-Ramírez, K. Ruiz-Saray, P. E. Oceguera-Basurto, M. Almada, J. Juárez, A. ZepedaMoreno, A. Del Toro-Arreola, A. Topete and A. DaneriNavarro, Cisplatin-loaded PLGA nanoparticles for HER2 targeted ovarian cancer therapy, Colloids Surf., B, 2019, 178, 199-207.

46 M. Dunne, I. Corrigan and Z. Ramtoola, Influence of particle size and dissolution conditions on the degradation properties of polylactide-co-glycolide particles, Biomaterials, 2000, 21, 1659-1668.

47 S. Lappe, D. Mulac and K. Langer, Polymeric nanoparticles - Influence of the glass transition temperature on drug release, Int. J. Pharm., 2017, 517, 338-347.

48 K. Park, A. Otte, F. Sharifi, J. Garner, S. Skidmore, H. Park, Y. K. Jhon, B. Qin and Y. Wang, Potential roles of the glass transition temperature of PLGA microparticles in drug release kinetics, Mol. Pharm., 2021, 18, 18-32.

49 D. P. Santos, M. A. Ruiz, V. Gallardo, M. V. B. Zanoni and J. L. Arias, Multifunctional antitumor magnetite/chitosanl-glutamic acid (core/shell) nanocomposites, J. Nanopart. Res., 2011, 13, 4311-4323.

50 F. Assa, H. Jafarizadeh-Malmiri, H. Ajamein, H. Vaghari, N. Anarjan, O. Ahmadi and A. Berenjian, Chitosan magnetic nanoparticles for drug delivery systems, Crit. Rev. Biotechnol., 2017, 37, 492-509.

51 L. S. Arias, J. P. Pessan, F. N. de Souza Neto, B. H. R. Lima, E. R. de Camargo, G. Ramage, A. C. B. Delbem and D. R. Monteiro, Novel nanocarrier of miconazole based on chitosan-coated iron oxide nanoparticles as a nanotherapy to fight Candida biofilms, Colloids Surf., B, 2020, 192, 111080.

52 B. Sarmento, D. Mazzaglia, M. C. Bonferoni, A. P. Neto, M. do Céu Monteiro and V. Seabra, Effect of chitosan coating in overcoming the phagocytosis of insulin loaded solid lipid nanoparticles by mononuclear phagocyte system, Carbohydr. Polym., 2011, 84, 919-925.

53 S. A. Abouelmagd, Y. J. Ku and Y. Yeo, Low molecular weight chitosan-coated polymeric nanoparticles for sustained and $\mathrm{pH}$-sensitive delivery of paclitaxel, J. Drug Targeting, 2015, 23, 725-735.

54 D. Chirio, E. Peira, S. Sapino, C. Dianzani, A. Barge, E. Muntoni, S. Morel and M. Gallarate, Stearoyl-chitosan coated nanoparticles obtained by microemulsion cold dilution technique, Int. J. Mol. Sci., 2018, 19, 3833.

55 R. A. Ishak, G. A. Awad, N. M. Zaki, Ael-H El-Shamy and N. D. Mortada, A comparative study of chitosan shielding effect on nano-carriers hydrophilicity and biodistribution, Carbohydr. Polym., 2013, 94, 669-676.

56 L. Chronopoulou, M. Massimi, M. F. Giardi, C. Cametti, L. C. Devirgiliis, M. Dentini and C. Palocci, Chitosancoated PLGA nanoparticles: a sustained drug release strategy for cell cultures, Colloids Surf., B, 2013, 103, 310-317.

57 W. Li, M. Yalcin, Q. Lin, M. M. Ardawi and S. A. Mousa, Self-assembly of green tea catechin derivatives in nanoparticles for oral lycopene delivery, J. Controlled Release, 2017, 248, 117-124.

58 H. Chen, W. Yang, H. Chen, L. Liu, F. Gao, X. Yang, Q. Jiang, Q. Zhang and Y. Wang, Surface modification of mitoxantrone-loaded PLGA nanospheres with chitosan, Colloids Surf., B, 2009, 73, 212-218.

59 S. Kashyap, A. Singh, A. Mishra and V. Singh, Enhanced sustained release of furosemide in long circulating chitosan-conjugated PLGA nanoparticles, Results Pharma Sci., 2019, 14, 93-106.

60 B. Lu, X. Lv and Y. Le, Chitosan-modified PLGA nanoparticles for control-released drug delivery, Polymers, 2019, 11, 304 .

61 K. Tahara, H. Yamamoto, N. Hirashima and Y. Kawashima, Chitosan-modified poly(D,L-lactide-co-glycolide) nanospheres for improving siRNA delivery and gene-silencing effects, Eur. J. Pharm. Biopharm., 2010, 74, 421-426.

62 Z. G. Yue, W. Wei, P. P. Lv, H. Yue, L. Y. Wang, Z. G. Su and G. H. Ma, Surface Charge Affects Cellular Uptake and Intracellular Trafficking of Chitosan-Based Nanoparticles, Biomacromolecules, 2011, 12, 2440-2446.

63 S. H. Voon, S. X. Tiew, C. S. Kue, H. B. Lee, L. V. Kiew, M. Misran, A. Kamkaew, K. Burgess and L. Y. Chung, Chitosan-coated poly(lactic-co-glycolic acid)-diiodinated boron-dipyrromethene nanoparticles improve tumor selectivity and stealth properties in photodynamic cancer therapy, J. Biomed. Nanotechnol., 2016, 12, 1431-1452.

64 A. Babu, N. Amreddy, R. Muralidharan, G. Pathuri, H. Gali, A. Chen, Y. D. Zhao, A. Munshi and R. Ramesh, Chemodrug delivery using integrin-targeted PLGA-Chitosan nanoparticle for lung cancer therapy, Sci. Rep., 2017, 7, 14674.

65 M. M. Badran, A. H. Alomrani, G. I. Harisa, A. E. Ashour, A. Kumar and A. E. Yassin, Novel docetaxel chitosan-coated PLGA/PCL nanoparticles with magnified cytotoxicity and bioavailability, Biomed. Pharmacother., 2018, 106, 1461-1468.

66 S. Caban-Toktas, A. Sahin, S. Lule, G. Esendagli, I. Vural, K. Karlı Oguz, F. Soylemezoglu, M. Mut, T. Dalkara, M. Khan and Y. Capan, Combination of paclitaxel and R-flurbiprofen loaded PLGA nanoparticles suppresses 
glioblastoma growth on systemic administration, Int. J. Pharm., 2020, 578, 119076.

67 V. Cricchio, M. Best, E. Reverchon, N. Maffulli, G. Phillips, M. Santin and G. Della Porta, Novel superparamagnetic microdevices based on magnetized PLGA/PLA microparticles obtained by supercritical fluid emulsion and coating by carboxybetaine-functionalized chitosan allowing the tuneable release of therapeutic, J. Pharm. Sci., 2017, 106, 2097-2105.

68 A. Shanavas, S. Sasidharan, D. Bahadur and R. Srivastava, Magnetic core-shell hybrid nanoparticles for receptor targeted anti-cancer therapy and magnetic resonance imaging, J. Colloid Interface Sci., 2017, 486, 112-120.

69 G. Li, Y. Wang and G. Tan, The construction of EpCAM/ vimentin-PLGA/lipid immunomagnetic microspheres and the isolation of circulating tumor cells from lung cancer, Int. J. Clin. Exp. Pathol., 2018, 11, 5561-5570.

70 R. Massart, Preparation of Aqueous Magnetic Liquids in Alkaline and Acidic Media, IEEE Trans. Magn., 1981, 17, 1247-1248.

71 A. Bee, R. Massart and S. Neveu, Synthesis of very fine maghemite particles, J. Magn. Magn. Mater., 1995, 149, 6-9.

72 L. N. Okassa, H. Marchais, L. Douziech-Eyrolles, K. Hervé, S. Cohen-Jonathan, E. Munnier, M. Soucé, C. Linassier, P. Dubois and I. Chourpa, Optimization of iron oxide nanoparticles encapsulation within poly(D,L-lactide-coglycolide) sub-micron particles, Eur. J. Pharm. Biopharm., 2007, 67, 31-38.

73 T. J. Matshaya, A. E. Lanterna, A. M. Granados, R. W. Krause, B. Maggio and R. V. Vico, Distinctive interactions of oleic acid covered magnetic nanoparticles with saturated and unsaturated phospholipids in Langmuir monolayers, Langmuir, 2014, 30, 5888-5896.

74 J. Ibarra, J. Melendres, M. Almada, M. G. Burboa, P. Taboada, J. Juárez and M. A. Valdez, Synthesis and characterization of magnetite/PLGA/chitosan nanoparticles, Mater. Res. Express, 2015, 2, 1-17.

75 M. A. Holgado, J. Alvarez-Fuentes, M. Fernández-Arévalo and J. L. Arias, Possibilities of poly(d,l-lactide-co-glycolide) in the formulation of nanomedicines against cancer, Curr. Drug Targets, 2011, 12, 1096-1111.

76 L. Martín-Banderas, I. Muñoz-Rubio, J. Álvarez-Fuentes, M. Durán-Lobato, J. L. Arias, M. Á. Holgado and M. Fernández-Arévalo, Engineering of $\Delta$ 9-tetrahydrocannabinol delivery systems based on surface modifiedPLGA nanoplatforms, Colloids Surf., B, 2014, 123, 114-122.

77 J. L. Arias, M. López-Viota, V. Gallardo and M. A. Ruiz, Chitosan nanoparticles as a new delivery system for the chemotherapy agent tegafur, Drug Dev. Ind. Pharm., 2010, 36, 744-750.

78 J. L. Arias, L. H. Reddy and P. Couvreur, Superior preclinical efficacy of gemcitabine developed as chitosan nanoparticulate system, Biomacromolecules, 2011, 12, 97-104.

79 J. D. Unciti-Broceta, J. L. Arias, J. Maceira, M. Soriano, M. Ortiz-González, J. Hernández-Quero, M. Muñóz-Torres, H. P. de Koning, S. Magez and J. A. Garcia-Salcedo, Specific
Cell Targeting Therapy Bypasses Drug Resistance Mechanisms in African Trypanosomiasis, PLoS Pathog., 2015, 11, e1004942.

80 H. L. Andersen, M. Saura-Múzquiz, C. Granados-Miralles, E. Canévet, N. Lock and M. Christensen, Crystalline and magnetic structure-property relationship in spinel ferrite nanoparticles, Nanoscale, 2018, 10, 14902-14914.

81 M. Di Marco, C. Sadun, M. Port, I. Guilbert, P. Couvreur and C. Dubernet, Physicochemical characterization of ultrasmall superparamagnetic iron oxide particles (USPIO) for biomedical application as MRI contrast agents, Int. J. Nanomed., 2007, 2, 609-622.

82 M. Pernia Leal, C. Caro and M. L. García-Martín, Shedding light on zwitterionic magnetic nanoparticles: limitations for in vivo applications, Nanoscale, 2017, 9, 8176-8184.

83 V. Nica, C. Caro, J. M. Páez-Muñoz, M. Pernia Leal and M. L. Garcia-Martin, Bi-magnetic core-shell $\mathrm{CoFe}_{2} \mathrm{O}_{4} @$ $\mathrm{MnFe}_{2} \mathrm{O}_{4}$ nanoparticles for in vivo theranostics, Nanomaterials, 2020, 10, 907.

84 J. L. Arias, M. López-Viota, E. Sáez-Fernández, M. A. Ruiz and A. V. Delgado, Engineering of an antitumor (core/ shell) magnetic nanoformulation based on the chemotherapy agent ftorafur, Colloids Surf., A, 2011, 384, 157-163.

85 B. C. Dash, G. Réthoré, M. Monaghan, K. Fitzgerald, W. Gallagher and A. Pandit, The influence of size and charge of chitosan/polyglutamic acid hollow spheres on cellular internalization, viability and blood compatibility, Biomaterials, 2010, 31, 8188-8197.

86 International Organization for Standardization. 2009. Biological evaluation of medical devices - part 5: tests for in vitro cytotoxicity (ISO 10993-5:2009).

87 B. Clares, R. A. Biedma-Ortiz, E. Sáez-Fernández, J. C. Prados, C. Melguizo, L. Cabeza, R. Ortiz and J. L. Arias, Nano-engineering of 5-fluorouracil-loaded magnetoliposomes for combined hyperthermia and chemotherapy against colon cancer, Eur. J. Pharm. Biopharm., 2013, 85, 329-338.

88 R. Hergt and S. Dutz, Magnetic particle hyperthermiabiophysical limitations of a visionary tumour therapy, J. Magn. Magn. Mater., 2007, 311, 187-192.

89 A. P. Khandhar, R. M. Ferguson, J. A. Simon and K. M. Krishnan, Tailored magnetic nanoparticles for optimizing magnetic fluid hyperthermia, J. Biomed. Mater. Res., Part A, 2012, 100, 728-737.

90 E. Fantechi, C. Innocenti, M. Zanardelli, M. Fittipaldi, E. Falvo, M. Carbo, V. Shullani, L. Di Cesare Mannelli, C. Ghelardini, A. M. Ferretti, A. Ponti, C. Sangregorio and P. Ceci, A smart platform for hyperthermia application in cancer treatment: cobalt-doped ferrite nanoparticles mineralized in human ferritin cages, ACS Nano, 2014, 8, 4705-4719.

91 C. Caro, C. M. Muñoz-Hernández, M. Pernia Leal and M. L. García-Martín, In vivo pharmacokinetics of magnetic nanoparticles, Methods. Mol. Biol., 2018, 1718, 409-419.

92 C. Caro, D. Egea-Benavente, R. Polvillo, J. L. Royo, M. Pernia Leal and M. L. García-Martín, Comprehensive 
toxicity assessment of PEGylated magnetic nanoparticles for in vivo applications, Colloids Surf., B, 2019, 177, 253-259.

93 H. Maeda, J. Wu, T. Sawa, Y. Matsumura and K. Hori, Tumor vascular permeability and the EPR effect in macromolecular therapeutics: a review, J. Controlled Release, 2000, 65, 271-284.

94 M. Gaumet, A. Vargas, R. Gurny and F. Delie, Nanoparticles for drug delivery: the need for precision in reporting particle size parameters, Eur. J. Pharm. Biopharm., 2008, 69, 1-9.

95 C. He, Y. Hu, L. Yin, C. Tang and C. Yin, Effects of particle size and surface charge on cellular uptake and biodistribution of polymeric nanoparticles, Biomaterials, 2010, 31, 3657-3666.

96 X. Liu, N. Huang, H. Li, Q. Jin and J. Ji, Surface and size effects on cell interaction of gold nanoparticles with both phagocytic and nonphagocytic cells, Langmuir, 2013, 29, 9138-9148.

97 J. L. Arias, M. A. Ruiz, V. Gallardo and A. V. Delgado, Tegafur loading and release properties of magnetite/poly(alkylcyanoacrylate) (core/shell) nanoparticles, J. Controlled Release, 2008, 125, 50-58.

98 J. L. Arias, V. Gallardo, M. A. Ruiz and A. V. Delgado, Magnetite/poly(alkylcyanoacrylate) (core/shell) nanoparticles as 5-Fluorouracil delivery systems for active targeting, Eur. J. Pharm. Biopharm., 2008, 69, 54-63.

99 S. Nasrazadani and S. Hassani, in Handbook of Materials Failure Analysis with Case Studies from the Oil and Gas Industry, ed. A. S. H. Makhlouf and M. Aliofkhazraei, Butterworth-Heinemann, Oxford, 2016, vol. 2, pp. 39-54.

100 M. A. Holgado, M. J. Cózar-Bernal, S. Salas, J. L. Arias, J. Alvarez-Fuentes and M. Fernández-Arévalo, Proteinloaded PLGA microparticles engineered by flow focusing: physicochemical characterization and protein detection by reversed-phase HPLC, Int. J. Pharm., 2009, 380, 147-154.

101 R. Di Corato, A. Aloisi, S. Rella, J. M. Greneche, G. Pugliese, T. Pellegrino, C. Malitesta and R. Rinaldi, Maghemite Nanoparticles with Enhanced Magnetic Properties: OnePot Preparation and Ultrastable Dextran Shell, ACS Appl. Mater. Interfaces, 2018, 10, 20271-20280.

102 J. Depeyrot, E. C. Sousa, R. Aquino, F. A. Tourinho, E. Dubois, J. C. Bacri and R. Perzynski, Rare earth doped maghemite EDL-MF: a perspective for nanoradiotherapy?, J. Magn. Magn. Mater., 2002, 252, 375-377.

103 Y. Ling, M. Long, P. Hu, Y. Chen and J. Huang, Magnetically separable core-shell structural $\gamma-\mathrm{Fe}_{2} \mathrm{O}_{3} @ \mathrm{Cu} / \mathrm{Al}-\mathrm{MCM}$ 41 nanocomposite and its performance in heterogeneous Fenton catalysis, J. Hazard. Mater., 2014, 264, 195-202.

104 S. Narimani-Sabegh and E. Noroozian, Magnetic solidphase extraction and determination of ultra-trace amounts of antimony in aqueous solutions using maghemite nanoparticles, Food Chem., 2019, 287, 382-389.

105 I. Berry, S. Benderbous, J. P. Ranjeva, D. Gracia-Meavilla, C. Manelfe and D. Le Bihan, Contribution of Sinerem used as blood-pool contrast agent: detection of cerebral blood volume changes during apnea in the rabbit, Magn. Reson. Med., 1996, 36, 415-419.

106 S. Laurent, D. Forge, M. Port, A. Roch, C. Robic, L. Vander Elst and R. N. Muller, Magnetic iron oxide nanoparticles: synthesis, stabilization, vectorization, physicochemical characterizations, and biological applications, Chem. Rev., 2008, 108, 2064-2110.

107 G. B. Toth, C. G. Varallyay, A. Horvath, M. R. Bashir, P. L. Choyke, H. E. Daldrup-Link, E. Dosa, J. P. Finn, S. Gahramanov, M. Harisinghani, I. Macdougall, A. Neuwelt, S. S. Vasanawala, P. Ambady, R. Barajas, J. S. Cetas, J. Ciporen, T. J. DeLoughery, N. D. Doolittle, R. Fu, J. Grinstead, A. R. Guimaraes, B. E. Hamilton, X. Li, H. L. McConnell, L. L. Muldoon, G. Nesbit, J. P. Netto, D. Petterson, W. D. Rooney, D. Schwartz, L. Szidonya and E. A. Neuwelt, Current and potential imaging applications of ferumoxytol for magnetic resonance imaging, Kidney Int., 2017, 92, 47-66.

108 P. Caravan, J. J. Ellison, T. J. McMurry and R. B. Lauffer, Gadolinium(III) chelates as MRI contrast agents: structure, dynamics, and applications, Chem. Rev., 1999, 99, 2293-2352.

109 A. Pandey, N. Dhas, P. Deshmukh, C. Caro, P. Patil, M. L. García-Martín, B. Padya, A. Nikam, T. Mehta and S. Mutalik, Heterogeneous surface architectured metalorganic frameworks for cancer therapy, imaging, and biosensing: a state-of-the-art review, Coord. Chem. Rev., 2020, 409, 213212.

$110 \mathrm{~S}$. Fucharoen and V. Viprakasit, $\mathrm{Hb} \mathrm{H}$ disease: clinical course and disease modifiers, Hematology Am. Soc. Hematol. Educ. Program., 2009, 26, 34.

111 P. I. Soares, I. M. Ferreira, R. A. Igreja, C. M. Novo and J. P. Borges, Application of hyperthermia for cancer treatment: recent patents review, Recent Pat. Anti-Cancer Drug Discovery, 2012, 7, 64-73.

112 L. Beola, L. Asín, R. M. Fratila, V. Herrero, J. M. de la Fuente, V. Grazú and L. Gutiérrez, Dual role of magnetic nanoparticles as intracellular hotspots and extracellular matrix disruptors triggered by magnetic hyperthermia in 3D cell culture models, ACS Appl. Mater. Interfaces, 2018, 10, 44301-44313.

113 R. Gupta and D. Sharma, Biofunctionalization of magnetite nanoparticles with stevioside: effect on the size and thermal behaviour for use in hyperthermia applications, Int. J. Hyperthermia, 2019, 36, 302-312.

114 S. Dutz and R. Hergt, Magnetic particle hyperthermia--a promising tumour therapy?, Nanotechnology, 2014, 25, 452001.

115 M. Kettering, I. Grau, N. Pömpner, M. Stapf, M. Gajda, U. Teichgräber and I. Hilger, Means to increase the therapeutic efficiency of magnetic heating of tumors, Biomed. Technol., 2015, 60, 505-517.

116 S. L. Easo and P. V. Mohanan, Dextran stabilized iron oxide nanoparticles: synthesis, characterization and in vitro studies, Carbohydr. Polym., 2013, 92, 726-732. 
117 S. V. Jadhav, P. S. Shewale, B. C. Shin, M. P. Patil, G. D. Kim, A. A. Rokade, S. S. Park, R. A. Bohara and Y. S. Yu, Study of structural and magnetic properties and heat induction of gadolinium-substituted manganese zinc ferrite nanoparticles for in vitro magnetic fluid hyperthermia, J. Colloid Interface Sci., 2019, 541, 192-203.
118 S. Y. Lee, E. Jung, J. H. Park, J. W. Park, C. K. Shim, D. D. Kim, I. S. Yoon and H. J. Cho, Transient aggregation of chitosan-modified poly(D,L-lactic-co-glycolic) acid nanoparticles in the blood stream and improved lung targeting efficiency, J. Colloid Interface Sci., 2016, 480, 102-108. 